Atmos. Chem. Phys., 10, 4909-4929, 2010

www.atmos-chem-phys.net/10/4909/2010/

doi:10.5194/acp-10-4909-2010

(C) Author(s) 2010. CC Attribution 3.0 License.

\title{
Multi-year (2004-2008) record of nonmethane hydrocarbons and halocarbons in New England: seasonal variations and regional
} sources

\author{
R. S. Russo, Y. Zhou, M. L. White, H. Mao, R. Talbot, and B. C. Sive \\ Climate Change Research Center, Institute for the Study of Earth, Oceans, and Space, University of New Hampshire, \\ Durham, NH 03824, USA
}

Received: 15 November 2009 - Published in Atmos. Chem. Phys. Discuss.: 18 January 2010

Revised: 3 May 2010 - Accepted: 14 May 2010 - Published: 27 May 2010

\begin{abstract}
Multi-year time series records of $\mathrm{C}_{2}-\mathrm{C}_{6}$ alkanes, $\mathrm{C}_{2}-\mathrm{C}_{4}$ alkenes, ethyne, isoprene, $\mathrm{C}_{6}-\mathrm{C}_{8}$ aromatics, trichloroethene $\left(\mathrm{C}_{2} \mathrm{HCl}_{3}\right)$, and tetrachloroethene $\left(\mathrm{C}_{2} \mathrm{Cl}_{4}\right)$ from canister samples collected during January 2004February 2008 at the University of New Hampshire (UNH) AIRMAP Observatory at Thompson Farm (TF) in Durham, $\mathrm{NH}$ are presented. The objectives of this work are to identify the sources of nonmethane hydrocarbons (NMHCs) and halocarbons observed at TF, characterize the seasonal and interannual variability in ambient mixing ratios and sources, and estimate regional emission rates of NMHCs. Analysis of correlations and comparisons with emission ratios indicated that a ubiquitous and persistent mix of emissions from several anthropogenic sources is observed throughout the entire year. The highest $\mathrm{C}_{2}-\mathrm{C}_{8}$ anthropogenic NMHC mixing ratios were observed in mid to late winter. Following the springtime minimums, the $\mathrm{C}_{3}-\mathrm{C}_{6}$ alkanes, $\mathrm{C}_{7}-\mathrm{C}_{8}$ aromatics, and $\mathrm{C}_{2} \mathrm{HCl}_{3}$ increased in early to mid summer, presumably reflecting enhanced evaporative emissions. Mixing ratios of $\mathrm{C}_{2} \mathrm{Cl}_{4}$ and $\mathrm{C}_{2} \mathrm{HCl}_{3}$ decreased by $0.7 \pm 0.2$ and $0.3 \pm 0.05 \mathrm{pptv} / \mathrm{year}$, respectively, which is indicative of reduced usage and emissions of these halogenated solvents. Emission rates of $\mathrm{C}_{3}-\mathrm{C}_{8} \mathrm{NMHCs}$ were estimated to be $10^{9}$ to $10^{10}$ molecules $\mathrm{cm}^{-2} \mathrm{~s}^{-1}$ in winter 2006 . The emission rates extrapolated to the state of New Hampshire and New England were $\sim 2-60 \mathrm{Mg} /$ day and $\sim 12-430 \mathrm{Mg} /$ day, respectively. Emission rates of benzene, toluene, ethylbenzene,
\end{abstract}

Correspondence to: R. S. Russo

(rrusso@gust.sr.unh.edu) xylenes, and ethyne in the 2002 and 2005 EPA National Emissions Inventories were within $\pm 50 \%$ of the TF emission rates.

\section{Introduction}

Volatile organic compounds (VOCs) (including nonmethane hydrocarbons (NMHCs), alkyl nitrates, oxygenated and halogenated hydrocarbons) are ubiquitous and important chemical constituents in the atmosphere. The reaction of VOCs with various oxidants (e.g., hydroxyl radical $(\mathrm{OH})$, ozone $\left(\mathrm{O}_{3}\right)$, nitrate radical, halogens) produces organic $\left(\mathrm{RO}_{2}\right)$ and hydro $\left(\mathrm{HO}_{2}\right)$ peroxy radicals which react with nitrogen oxides $\left(\mathrm{NO}_{\mathrm{x}}\right)$ to produce secondary species, such as tropospheric ozone, organic nitrates, and peroxides, and regulates the oxidation capacity of the atmosphere. The relative concentrations and speciation of $\mathrm{NO}_{\mathrm{x}}$ and $\mathrm{NMHCs}$ in a particular region determine whether ozone production or destruction occurs (e.g., Carter, 1994; Sillman and He, 2002; Kleinman et al., 2005). In addition, the partitioning of low volatility VOC oxidation products into the condensed phase produces secondary organic aerosols (e.g., Odum et al., 1997; Ng et al., 2007; Kroll and Seinfeld, 2008). Ozone and aerosols are components of photochemical smog, are respiratory lung irritants, and are harmful to vegetation and crops. Furthermore, several VOCs, such as benzene, toluene, xylenes, and tetrachloroethene, are classified as toxic air pollutants and are subject to federal regulations (US EPA, 2008). Therefore, it is necessary to identify and characterize the atmospheric distributions and sources of VOCs in order to

Published by Copernicus Publications on behalf of the European Geosciences Union. 
develop and validate emission inventories, reduce the levels of hazardous air pollutants, and to predict and control $\mathrm{O}_{3}$ and aerosol concentrations.

The regional distributions of VOCs are highly variable because of several confounding factors, including different atmospheric lifetimes and removal mechanisms, varying meteorological conditions, and the wide range of potential sources. In order to minimize these complications and to eliminate site-to-site differences, long-term continuous measurements from the same location are necessary. Multi-year measurements of NMHCs and halocarbons at remote and urban North American sites have been reported (e.g., Jobson et al., 1994; Hagerman et al., 1997; Kang et al., 2001; Mohamed et al., 2002; Gautrois et al., 2003; Swanson et al., 2003; McCarthy et al., 2006; Qin et al., 2007), but not for New England since 1994-2001 (Goldstein et al., 1995; Kleiman and Prinn, 2000; Barnes et al., 2003; Lee et al., 2006). These studies have provided baseline data from which to monitor future changes in sources and ambient mixing ratios.

Air masses containing urban and industrial emissions from southern New England, the US East Coast and mid-Atlantic corridor, and the Midwest are transported to New Hampshire. Previous research has indicated that the trace gas measurements (including $\mathrm{O}_{3}$, carbon monoxide $(\mathrm{CO})$, nitric oxide (NO), mercury, select VOCs) made at the UNH AIRMAP monitoring site at Thompson Farm (TF) in Durham, New Hampshire are representative of both inland and coastal New England (e.g., Talbot et al., 2005; Chen et al., 2007; Sive et al., 2007; Mao et al., 2008; White et al., 2008; Zhou et al., 2005, 2008). This suggests that the TF results can be applied to regional analyses of the short and long-term temporal variability and sources of VOCs for this region. This is particularly valuable because southern New England, including the seacoast region of New Hampshire, and extending to the southwest through New York and New Jersey is classified as an $\mathrm{O}_{3}$ nonattainment area (US EPA, 2003, 2008).

We have been conducting VOC measurements at Thompson Farm since 2002. Multi-year VOC data published thus far includes measurements of $\mathrm{C}_{1}-\mathrm{C}_{5}$ alkyl nitrates (Russo et al., 2010), methyl iodide (Sive et al., 2007), and oxygenated VOCs (OVOCs) and select NMHCs (Jordan et al., 2009). Summertime measurements (2002-2004) of NMHCs, OVOCs, and marine-derived halocarbons at TF were discussed in Talbot et al. (2005), Chen et al. (2007), White et al. (2008), and Zhou et al. (2005, 2008). In this work, four years (2004-2008) of ambient $\mathrm{C}_{2}-\mathrm{C}_{8} \mathrm{NMHC}$ and anthropogenic halocarbon data from daily canister samples collected at the Thompson Farm site in southeastern New Hampshire are presented and discussed. The primary objectives of this study are to characterize the seasonal to interannual trends and to identify the possible sources of $\mathrm{C}_{2}-\mathrm{C}_{8}$ NMHCs and halocarbons. Additionally, emission rates of several NMHCs were estimated and compared with the EPA National Emissions Inventory.

\section{Sampling and analytical methods}

\subsection{Daily canister sample collection and analysis}

The University of New Hampshire AIRMAP Observatory at Thompson Farm (TF) is located in Durham, New Hampshire $\left(43.11^{\circ} \mathrm{N}, 70.95^{\circ} \mathrm{W}\right.$, elevation $\left.24 \mathrm{~m}\right)$ and is located approximately $20 \mathrm{~km}$ inland from the Atlantic Ocean and $100 \mathrm{~km}$ north of Boston, MA (www.airmap.unh.edu) (Fig. 1). TF is surrounded by agricultural fields and a mixed deciduous and coniferous forest. An ambient canister sample has been collected at some point between 10:00-15:00 (EST; UTC-5 h) each day at the top of the $15 \mathrm{~m}$ tower next to the manifold inlet for all the instruments housed in the TF building. Sample collection began on 12 January 2004 and continues through the present. The sample collection time window is representative of daytime conditions when photochemistry is most active and the boundary layer is likely well mixed. Prior to sampling, the 2-liter electropolished stainless steel canisters (University of California, Irvine, CA) were prepared by flushing with UHP helium that had passed through an activated charcoal/molecular sieve (13X) trap immersed in liquid nitrogen. The canisters were then evacuated to $10^{-2}$ torr.

The canister samples were analyzed in the laboratory at UNH approximately every $1-3$ months for $\mathrm{C}_{2}-\mathrm{C}_{10}$ nonmethane hydrocarbons, $\mathrm{C}_{1}-\mathrm{C}_{5}$ alkyl nitrates, $\mathrm{C}_{1}-\mathrm{C}_{2}$ halocarbons, several OVOCs, and select sulfur compounds. A three gas chromatograph system equipped with two flame ionization detectors (FID), two electron capture detectors (ECD), and a mass spectrometer (MS) was used for analysis of each $1500 \mathrm{cc}$ (STP) sample aliquot. The PLOT-FID, OV-1701-ECD, and OV-624-MS column-detector combinations have remained the same throughout 2004-2008 (see Sive et al. (2005) and Zhou et al. (2005, 2006, 2008) for additional information). In 2006, the FID channel used for $\mathrm{C}_{4}-\mathrm{C}_{10} \mathrm{NMHC}$ analysis was changed from a DB-1 column $(60 \mathrm{~m} \times 0.32 \mathrm{~mm}$ I.D., $1 \mu \mathrm{m}$ film thickness) to a VF-1ms column $(60 \mathrm{~m} \times 0.32 \mathrm{~mm}$ I.D., $1 \mu \mathrm{m}$ film thickness). Also, the OV-624-ECD channel was changed to a CP-PoraBond-Q column $(25 \mathrm{~m} \times 0.25 \mathrm{~mm}$ I.D., $3 \mu \mathrm{m}$ film thickness $)$ coupled to a Restek XTI-5 column $(30 \mathrm{~m} \times 0.25 \mathrm{~mm}$ I.D., $0.25 \mu \mathrm{m}$ film thickness). The MS was operated in electron impact mode with single ion monitoring for measuring OVOCs and sulfur compounds, as well as duplicate measurements of several halocarbons and NMHCs. A $1500 \mathrm{cc}$ aliquot from one of two working standards was assayed every ninth analysis. The measurement precision for the whole air standards (i.e., relative standard deviation $(\mathrm{RSD})=$ standard deviation of peak areas/average of peak areas) was $<1-4 \%$ for the $\mathrm{C}_{2}-\mathrm{C}_{8}$ NMHCs and $5 \%$ for $\mathrm{C}_{2} \mathrm{HCl}_{3}$ and $\mathrm{C}_{2} \mathrm{Cl}_{4}$ at 0.50 and $6.0 \mathrm{pptv}$, respectively. 


\subsection{Daily canister sample data set}

Data for several classes of NMHCs and two halocarbons from the canister samples collected during 12 January 2004 to 8 February 2008 were used for this study. Collection of the daily samples is ongoing. The specific compounds, which represent a wide range of chemical reactivities and sources, are $\mathrm{C}_{2}-\mathrm{C}_{6}$ alkanes (ethane, propane, ibutane, n-butane, i-pentane, n-pentane, n-hexane), $\mathrm{C}_{2}-\mathrm{C}_{4}$ alkenes (ethene, propene, 1-butene), $\mathrm{C}_{6}-\mathrm{C}_{8}$ aromatics (benzene, toluene, ethylbenzene, $\mathrm{m}+\mathrm{p}$-xylene, o-xylene), ethyne, isoprene, tetrachloroethene $\left(\mathrm{C}_{2} \mathrm{Cl}_{4}\right)$, and trichloroethene $\left(\mathrm{C}_{2} \mathrm{HCl}_{3}\right)$. The data for each year and for the combined four year data set was separated into four seasons which are defined as winter: December, January, February; spring: March, April, May; summer: June, July, August; and fall: September, October, November. Note that the data encompasses five winter seasons (2004-2008) and four spring, summer, and fall seasons (2004-2007) with the exceptions of winter 2004 which only includes 12 January to 29 February and winter 2008 which is only through 8 February. Mixing ratios higher than the 95th percentile value for each month were removed in order to ensure that the results were representative of typical conditions and were not skewed by outlying or spurious data points.

\subsection{Thompson Farm automated gas chromatograph}

Hourly measurements of $\mathrm{C}_{3}-\mathrm{C}_{6}$ alkanes, ethyne, propene, benzene, toluene, ethylbenzene, $\mathrm{m}+\mathrm{p}$-xylene, and o-xylene from an automated GC system during December 2005January 2006 at TF were also used in this analysis. The sample size of the in situ GC system was also $1500 \mathrm{cc}$. Details of the four channel (2 FIDs, 1 ECD, 1 MS) GC system, MMR preconcentrator, sample trapping and splitting, calibrations, and instrument control are given in Sive et al. (2005). The system deployed at TF also contained four channels, but VOC detection was made with two FIDs and two ECDs. The channel which replaced the MS was a PoraBond-Q/OV-1 column coupled to an ECD for measuring $\mathrm{C}_{1}-\mathrm{C}_{2}$ halocarbons. A $1500 \mathrm{cc}$ aliquot from one of two working standards was assayed every tenth analysis. The precision (i.e., RSD) for each of the hydrocarbons discussed in this work ranged from $3-10 \%$.

\subsection{Standards and calibration}

In order to ensure that the VOC mixing ratios in samples analyzed at different times are comparable, whole air and synthetic standards were routinely analyzed and calibration scales were cross referenced and validated. When conducting the canister sample analysis, one of two whole air standards was analyzed after every eighth sample in order to monitor changes in detector sensitivity and measurement precision and to quickly detect any analytical problems. The

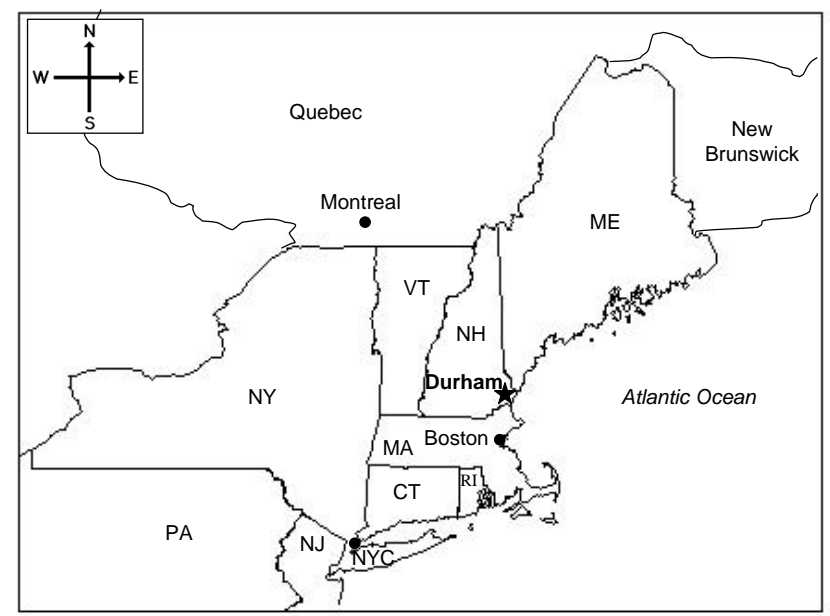

Fig. 1. Location of the UNH AIRMAP Atmospheric Observing Station at Thompson Farm in Durham, New Hampshire.

whole air working standards employed for this work have mixing ratios representative of clean free tropospheric air and suburban air, thus bracketing the low and high ranges for the measurements at TF. Moreover, linearity studies are regularly conducted to evaluate the detector response over the observed mixing ratio ranges for all classes of compounds. The working standards are part of the larger network of whole air standards maintained by B. Sive at $\mathrm{UNH}$ as part of the AIRMAP program. In total, there are currently ten high pressure cylinders, six 36-liter electropolished low-pressure pontoons $(\sim 350 \mathrm{psi})$, and three 34-liter electropolished highpressure pontoons $(\sim 900 \mathrm{psi})$ containing whole air standards that have been filled and calibrated by UCI (D. Blake) and UNH. We estimate the upper limit of the absolute accuracy of the calibrated standards to be on the order of $\pm 1-5 \%$ for the gases reported here. In addition to the whole air standards, calibrations are conducted using five different high-pressure cylinders containing synthetic blends of selected NMHCs, OVOCs, and halocarbons at the ppbv level (Apel-Reimer Environmental, Inc.). The absolute accuracy for all of the gases in the synthetic standards is less than $\pm 5 \%$.

Response factors (RF) for each compound in a particular standard were calculated by dividing the detector response (peak area=A) by the mixing ratio (MR) of that compound in the standard $(\mathrm{RF}=\mathrm{A} / \mathrm{MR})$. Mixing ratios for each gas to be quantified in the ambient samples were subsequently calculated using the average RF determined from the whole air standards during each set of individual analyses. In order to monitor the response of NMHCs with different numbers of carbon atoms, it is useful to evaluate the per-carbon response, particularly when dealing with long-term calibrations. The per-carbon response provides information regarding analytical system performance and standard integrity with time. The per-carbon response factors (PCRF) were determined by dividing the RF for each NMHC by the number of carbon 

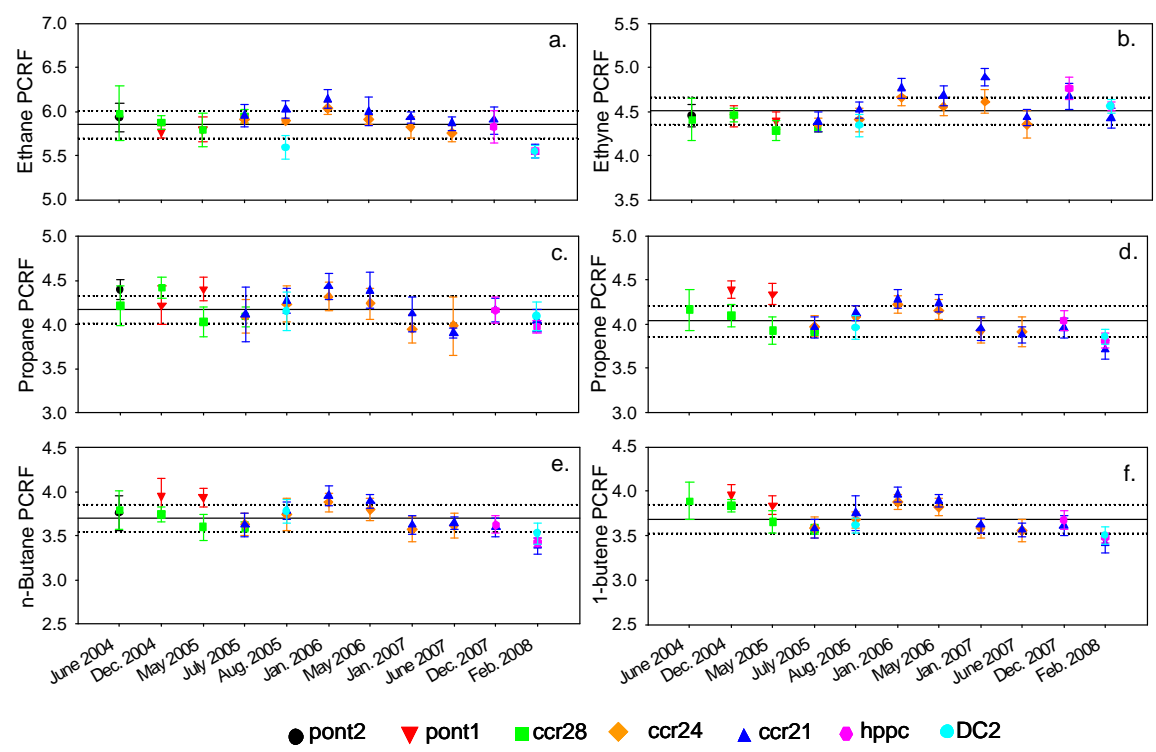

Fig. 2. Per carbon response factors (PCRF) of (a) ethane, (b) ethyne, (c) propane, (d) propene, (e) n-butane, and (f) 1-butene in different standards (pont1, pont2, ccrXY, hppc, DC2) analyzed in the UNH laboratory during 2004-2008. The reference lines are the mean \pm 1 standard deviation of the PCRF included in each plot. The symbols \pm error bars are the mean PCRF \pm 1 relative standard deviation for the individual standard analyzed during the specified time period.

atoms $(\mathrm{C})$ in each particular hydrocarbon $(\mathrm{PCRF}=\mathrm{RF} / \mathrm{C})$. While the response for hydrocarbons containing the same number of carbon atoms should be uniform, this should always be verified by analyzing different classes of compounds (e.g., alkanes, alkenes, alkynes). Examples of the PCRFs for several NMHCs are shown in Fig. 2 as representative examples for the analyses when a new standard began to be used and every $\sim 3-6$ months when the same two standards were being analyzed throughout 2004-2008. While there is some scatter about the mean PCRF over the four years, the PCRF of the two standards analyzed during each analysis period are self-consistent. Moreover, this illustrates the long-term stability of our analytical system.

The PCRF of the $\mathrm{C}_{2}-\mathrm{C}_{4}$ NMHCs measured with the PLOT-FID column-detector pair decreased with increasing carbon number, but remained approximately the same over the four years and did not vary with standard. Additionally, the PCRFs remained constant for the $\mathrm{C}_{3}$ (mean \pm standard deviation $=4.12 \pm 0.19)$ and $\mathrm{C}_{4}(3.70 \pm 0.16)$ compounds (Fig. 2c-f). The PCRFs of the $\mathrm{C}_{4}-\mathrm{C}_{10}$ NMHCs for the DB1/VF-1ms-FID column-detector pair have remained essentially constant $(1.43 \pm 0.03)$ for compounds with different carbon numbers and for different compound classes since 2005 (Sive, 1998; Zhou, 2006). Periodically, the standards used by the automated GC system at TF were returned to the laboratory and analyzed on the canister analysis system. The PCRFs for the TF standards (e.g., DC2) agreed (within $\pm 5 \%$ ) with the laboratory standards ensuring that the measurements made by the two independent systems are comparable.

\section{Seasonal and interannual variability of VOCs at Thompson Farm}

\subsection{General characteristics of NMHCs and comparison with previous studies}

The highest monthly mean and median mixing ratios of NMHCs (excluding isoprene, Sect. 3.2) at TF were observed in the winter (Fig. 3, Table 1). This reflects the slow removal rates from the atmosphere caused by minimum $\mathrm{OH}$ radical concentrations at this time of year. Lower boundary layer heights in winter are conducive to the build up of trace gas concentrations and may also contribute to the wintertime peak mixing ratios. In general, the lowest NMHC mixing ratios were observed in spring to summer when the maximum $\mathrm{OH}$ concentrations occur and the photochemical removal of NMHCs is the most rapid. It should also be mentioned that there is a variation in dominant air mass transport pathways throughout the year which may contribute to the seasonal variation in NMHC mixing ratios. For example, in the winter, the transport of clean, Canadian air masses to New England, which are representative of background conditions, is more frequent (Munger et al., 1996; Moody et al., 1998; Shipham et al., 1998). In contrast, transport from the south and west is more frequent during the summer (Moody et al., 1998; Fischer et al., 2004; Mao and Talbot, 2004b). Overall, the seasonal variation at TF is consistent with the general tropospheric trend observed at other North American sites (e.g., Jobson et al., 1994; Bottenheim and Shepherd, 1995; Goldstein et al., 1995; Hagerman et al., 1997; Gautrois et al., 2003; Swanson et al., 2003; Lee et al., 2006; Qin et al., 2007). 
Table 1. Monthly NMHC statistics (pptv) for January 2004-February 2008. SD is the standard deviation. $N$ is the number of samples.

\begin{tabular}{|c|c|c|c|c|c|c|c|c|c|c|c|c|}
\hline & January & February & March & April & May & June & July & August & September & October & November & December \\
\hline \multicolumn{13}{|l|}{ Ethane } \\
\hline Mean (SD) & $2436(621)$ & 2395 (443) & $2138(435)$ & $1856(278)$ & $1423(205)$ & $1104(306)$ & $1023(324)$ & $876(277)$ & $998(275)$ & $1238(367)$ & $1859(544)$ & 2278 \\
\hline $\operatorname{Median}(N)$ & $2248(125)$ & $2288(101)$ & 2104 (98) & $1835(86)$ & 1401 (102) & 1057 (92) & $942(91)$ & 784 (99) & $961(103)$ & $1099(86)$ & 1734 (94) & $2074(94)$ \\
\hline Range & $984-4673$ & $1656-3901$ & $872-3709$ & $947-2604$ & 859-2079 & 488-2049 & $453-2655$ & $465-1765$ & $530-1815$ & $720-2567$ & $881-3778$ & $1085-7622$ \\
\hline \multicolumn{13}{|l|}{ Propane } \\
\hline Mean (SD) & $1498(612)$ & $1332(481)$ & $1002(371)$ & $674(231)$ & 444 (204) & $497(340)$ & $559(308)$ & $505(314)$ & $605(331)$ & $786(471)$ & $1217(527)$ & $1518(795)$ \\
\hline $\operatorname{Median}(N)$ & $1309(125)$ & $1161(101)$ & $933(98)$ & $622(86)$ & 387 (102) & $380(92)$ & $522(91)$ & 399 (99) & $532(103)$ & $666(86)$ & $1164(94)$ & $1299(94)$ \\
\hline Range & 439-3907 & 806-3128 & $358-2419$ & $225-1682$ & $125-1135$ & $103-1488$ & $137-1600$ & $91-1647$ & $134-1766$ & 274-3229 & $446-2788$ & $608-4549$ \\
\hline \multicolumn{13}{|l|}{ i-Butane } \\
\hline Mean (SD) & 269 (109) & 253 (109) & $190(116)$ & $98(46)$ & $54(26)$ & $65(39)$ & $70(39)$ & $60(36)$ & 75 (59) & $126(67)$ & $210(99)$ & $266(144)$ \\
\hline $\operatorname{Median}(N)$ & 234 (125) & 220 (99) & $163(96)$ & $89(86)$ & 47 (102) & $57(92)$ & $64(92)$ & 46 (99) & $58(103)$ & $106(86)$ & 201 (94) & $225(94)$ \\
\hline \multirow{2}{*}{\multicolumn{13}{|c|}{ n-Butane }} \\
\hline & & & & & & & & & & & & \\
\hline Mean (SD) & $500(208)$ & 444 (169) & 308 (138) & $174(86)$ & $96(48)$ & $103(73)$ & 105 (59) & $95(61)$ & $118(81)$ & $217(125)$ & 376 (191) & $502(349)$ \\
\hline $\operatorname{Median}(N)$ & $429(125)$ & 400 (101) & $279(98)$ & $153(86)$ & 85 (102) & $72(92)$ & $92(92)$ & 78 (99) & 99 (103) & $180(85)$ & 333 (93) & $422(93)$ \\
\hline Range & $111-1325$ & $261-1230$ & $108-708$ & $29-423$ & $19-227$ & $16-349$ & $26-350$ & $10-271$ & $21-478$ & 54-577 & $105-833$ & $171-2160$ \\
\hline \multicolumn{13}{|l|}{ i-Pentane } \\
\hline Mean (SD) & 202 (112) & $163(74)$ & $125(93)$ & $74(47)$ & $67(46)$ & $105(77)$ & $115(60)$ & $110(75)$ & $109(80)$ & $127(90)$ & 177 (104) & $211(140)$ \\
\hline $\operatorname{Median}(N)$ & $170(125)$ & $151(100)$ & 95 (98) & $63(86)$ & $59(102)$ & $79(92)$ & $106(92)$ & 88 (99) & $92(103)$ & $100(86)$ & $150(94)$ & $176(93)$ \\
\hline Range & 55-710 & 67-427 & $33-517$ & $13-216$ & $11-265$ & $15-341$ & $30-301$ & $17-377$ & 13-399 & $23-412$ & 46-467 & 59-767 \\
\hline \multicolumn{13}{|l|}{ n-Pentane } \\
\hline Mean (SD) & $129(61)$ & $101(38)$ & $72(43)$ & $40(23)$ & $34(20)$ & $45(30)$ & $52(28)$ & $51(34)$ & $52(35)$ & $66(42)$ & $104(53)$ & $135(83)$ \\
\hline $\operatorname{Median}(N)$ & 114 (125) & $91(100)$ & $60(98)$ & $33(86)$ & $31(102)$ & $38(92)$ & $49(92)$ & 44 (99) & 45 (103) & $57(86)$ & $88(94)$ & 114 (94) \\
\hline Range & 26-374 & $51-237$ & $21-235$ & 7-124 & 5-114 & $7-151$ & $12-140$ & $7-165$ & $10-168$ & $16-179$ & $19-250$ & 49-465 \\
\hline \multicolumn{13}{|l|}{ n-Hexane } \\
\hline Mean (SD) & $53(32)$ & $42(22)$ & $27(20)$ & $16(11)$ & $18(11)$ & $23(17)$ & $25(15)$ & $25(16)$ & $25(18)$ & $29(21)$ & $40(23)$ & $52(32)$ \\
\hline Median $(N)$ & $42(125)$ & $37(100)$ & $23(93)$ & $12(82)$ & $15(89)$ & $18(86)$ & $22(88)$ & $22(91)$ & $19(90)$ & $23(81)$ & $38(94)$ & $42(92)$ \\
\hline Range & 14-180 & $17-130$ & 3-116 & 3-59 & $2-51$ & 5-90 & 5-82 & 4-75 & 3-83 & 3-84 & 6-95 & $10-144$ \\
\hline \multicolumn{13}{|l|}{ Ethyne } \\
\hline Mean (SD) & $730(260)$ & 704 (177) & $560(157)$ & $394(94)$ & $256(68)$ & $215(121)$ & $235(108)$ & $203(98)$ & $222(107)$ & 318 (129) & 498 (198) & $624(230)$ \\
\hline $\operatorname{Median}(N)$ & $631(125)$ & $650(101)$ & $533(98)$ & $379(86)$ & $242(102)$ & $181(92)$ & $216(92)$ & $179(99)$ & $193(103)$ & $289(85)$ & 440 (93) & $588(93)$ \\
\hline Range & $222-1804$ & $475-1329$ & $251-1146$ & $184-723$ & $118-455$ & $80-643$ & $82-499$ & 56-515 & $72-614$ & $121-700$ & $247-1331$ & $318-1552$ \\
\hline Ethene & & & & & & & & & & & & \\
\hline Mean (SD) & 579 (387) & 437 (259) & $346(291)$ & 337 (335) & $216(185)$ & 216 (169) & $192(104)$ & 184 (136) & $192(118)$ & $240(154)$ & 437 (284) & $679(412)$ \\
\hline $\operatorname{Median}(N)$ & 455 (125) & 364 (101) & 257 (98) & $162(86)$ & 158 (102) & $165(92)$ & $177(91)$ & 155 (99) & 158 (103) & $209(86)$ & 380 (93) & $534(93)$ \\
\hline Range & $168-2552$ & $120-1245$ & $32-1270$ & $41-1181$ & $38-854$ & $31-788$ & $70-717$ & 36-938 & 41-552 & 57-758 & $87-1284$ & $141-2110$ \\
\hline Propene & & & & & & & & & & & & \\
\hline Mean (SD) & $89(72)$ & $66(48)$ & $52(37)$ & $38(20)$ & 43 (22) & $43(20)$ & $52(30)$ & $54(44)$ & $53(34)$ & $54(33)$ & $71(48)$ & $98(74)$ \\
\hline $\operatorname{Median}(N)$ & $64(125)$ & $50(101)$ & $38(98)$ & $34(86)$ & 37 (102) & $40(92)$ & $47(91)$ & 46 (99) & $42(103)$ & $43(86)$ & $57(93)$ & 75 (93) \\
\hline Range & $21-427$ & $9-244$ & 11-198 & 13-95 & $12-115$ & $10-94$ & $17-214$ & $11-295$ & 13-180 & $16-164$ & $15-212$ & $21-380$ \\
\hline 1-Butene & & & & & & & & & & & & \\
\hline Mean (SD) & $20(16)$ & $18(12)$ & $16(10)$ & $12(7)$ & $13(10)$ & $11(6)$ & $10(6)$ & $12(12)$ & $12(8)$ & $12(9)$ & $18(12)$ & $20(15)$ \\
\hline $\operatorname{Median}(N)$ & $14(120)$ & $14(95)$ & $13(94)$ & $9(79)$ & 11 (97) & $8(88)$ & $9(90)$ & $9(92)$ & $9(91)$ & $9(82)$ & $13(89)$ & $16(92)$ \\
\hline Range & 4-26 & 3-79 & 4-56 & 4-38 & 3-63 & $3-27$ & 5-47 & $2-81$ & $3-43$ & $3-43$ & 3-55 & 4-90 \\
\hline Isoprene & & & & & & & & & & & & \\
\hline Mean (SD) & $35(54)$ & $24(51)$ & $20(33)$ & $9(9)$ & $50(125)$ & $666(674)$ & $1278(848)$ & $1078(657)$ & $464(420)$ & $86(116)$ & $16(15)$ & $93(150)$ \\
\hline $\operatorname{Median}(N)$ & $17(40)$ & $10(34)$ & $9(23)$ & $5(31)$ & $15(84)$ & $376(92)$ & $1007(92)$ & $946(99)$ & $336(103)$ & $40(77)$ & $11(45)$ & $25(47)$ \\
\hline Range & 3-303 & $3-301$ & $3-149$ & 3-49 & $2-829$ & $13-3131$ & $176-3893$ & $103-3714$ & $26-2486$ & 3-566 & $2-72$ & $2-551$ \\
\hline Benzene & & & & & & & & & & & & \\
\hline Mean (SD) & $167(50)$ & $159(42)$ & $133(42)$ & $88(24)$ & $60(18)$ & $55(35)$ & $60(26)$ & $55(26)$ & $59(28)$ & $75(28)$ & $114(39)$ & $151(56)$ \\
\hline $\operatorname{Median}(N)$ & $152(125)$ & 148 (101) & $126(99)$ & $88(86)$ & $59(102)$ & $45(92)$ & $55(92)$ & $50(99)$ & 54 (103) & $69(85)$ & $110(94)$ & $136(94)$ \\
\hline Range & 61-364 & $108-372$ & $72-297$ & $42-182$ & $25-111$ & $18-207$ & $21-123$ & $9-136$ & 15-139 & $27-147$ & $46-229$ & $57-373$ \\
\hline Toluene & & & & & & & & & & & & \\
\hline Mean (SD) & $136(91)$ & $126(102)$ & $125(215)$ & $67(53)$ & 73 (48) & $109(74)$ & $106(68)$ & $91(63)$ & $102(80)$ & $99(80)$ & $122(87)$ & $131(85)$ \\
\hline $\operatorname{Median}(N)$ & 104 (125) & $96(101)$ & $61(99)$ & $49(86)$ & $56(100)$ & $92(92)$ & $87(91)$ & 74 (98) & 78 (103) & $77(85)$ & 101 (94) & $111(93)$ \\
\hline Range & $48-535$ & $40-621$ & $16-1979$ & $9-235$ & $13-203$ & $16-291$ & $31-379$ & $14-340$ & 6-375 & $16-352$ & $22-442$ & $33-416$ \\
\hline Ethylbenzen & & & & & & & & & & & & \\
\hline Mean (SD) & $18(12)$ & $16(9)$ & 15 (17) & $10(9)$ & $9(6)$ & $13(11)$ & $14(10)$ & $11(7)$ & $10(8)$ & $12(9)$ & $15(10)$ & 17 (12) \\
\hline $\operatorname{Median}(N)$ & $14(124)$ & $13(99)$ & 8 (99) & $7(87)$ & $8(98)$ & $10(89)$ & $11(90)$ & $9(99)$ & $8(102)$ & $10(86)$ & $11(94)$ & $14(94)$ \\
\hline Range & 4-68 & 4-45 & $3-118$ & 2-62 & $1-26$ & $0.7-60$ & 3-59 & $2-40$ & 2-34 & 2-44 & 3-44 & 5-57 \\
\hline m+p-Xylene & & & & & & & & & & & & \\
\hline Mean (SD) & $23(19)$ & $18(13)$ & $17(20)$ & $11(10)$ & $11(8)$ & $18(24)$ & $19(22)$ & $12(12)$ & $12(10)$ & $15(13)$ & $20(15)$ & $24(18)$ \\
\hline $\operatorname{Median}(N)$ & 15 (124) & 15 (99) & $8(99)$ & $8(87)$ & $8(98)$ & $10(89)$ & $12(90)$ & $8(99)$ & $8(102)$ & $12(86)$ & $16(94)$ & 19 (93) \\
\hline Range & 4-126 & 3-64 & $2-113$ & $1-47$ & $2-47$ & $0.6-150$ & $3-125$ & 2-85 & 2-47 & $2-73$ & 2-62 & 5-107 \\
\hline o-Xylene & & & & & & & & & & & & \\
\hline Mean (SD) & $13(11)$ & $10(7)$ & $9(10)$ & 7 (5) & $6(4)$ & $11(13)$ & $12(11)$ & $9(9)$ & $8(6)$ & $9(7)$ & $11(8)$ & $13(10)$ \\
\hline $\operatorname{Median}(N)$ & $9(123)$ & $9(97)$ & $5(98)$ & $5(86)$ & $5(98)$ & 7 (88) & $9(90)$ & $6(99)$ & $6(102)$ & $7(86)$ & $9(94)$ & $11(93)$ \\
\hline Range & $2-73$ & 2-33 & $1-61$ & $2-30$ & $1-22$ & $2-75$ & 2-62 & $1-61$ & $1-31$ & 2-39 & $1-36$ & 3-56 \\
\hline
\end{tabular}


The mixing ratios of NMHCs observed at TF are lower than those reported for major US cities (Baker et al., 2008), including Pittsburgh, PA (Millet et al., 2005), Dallas, TX (Qin et al., 2007), and Houston, TX (Gilman et al., 2009). The winter mean and median mixing ratios of ethyne, $\mathrm{C}_{2}$ $\mathrm{C}_{4}$ alkanes, n-pentane, and n-hexane at TF were comparable to background (monthly 10th percentile) mixing ratios observed at Harvard Forest (HF) in Massachusetts during 1992-2001 (Goldstein et al., 1995; Lee et al., 2006). Similar behavior was observed during summer with the exception of propane whose mean and median mixing ratios were comparable at TF and HF. It must be kept in mind that the HF results include nighttime data. Winter and summer daytime mixing ratios of ethane, ethene, and ethyne at TF were similar to or higher than levels in the SE US (Hagerman et al., 1997) and at Whiteface Mountain, NY (WFM) (Gong and Demerjian, 1997) while aromatic hydrocarbon mixing ratios were generally lower at TF. This may reflect reduced emissions of aromatic compounds since the 1990's. Additionally, the mixing ratios of $\mathrm{C}_{4}-\mathrm{C}_{6}$ alkanes at TF in winter were generally lower than observed at various Canadian sites in the mid-1990's which likely reflects the influence of the Arctic air mass and/or the weaker photochemical removal of NMHCs at higher latitudes (Jobson et al., 1994; Bottenheim and Shephard, 1995; Young et al., 1997; Gautrois et al., 2003). In summer, the $\mathrm{C}_{2}-\mathrm{C}_{6}$ alkanes, ethene, and ethyne were similar to or higher than values reported in Canada the previous decade, including the downwind site at Chebogue Point, Nova Scotia (Jobson et al., 1998). With the exception of HF, summertime mixing ratios of propane, ethene, and ethyne at TF were consistently higher than or similar to values reported for rural sites throughout the continental US and Canada. In contrast to the 1993 NARE campaign, the median mixing ratios of $\mathrm{C}_{3}-\mathrm{C}_{8}$ NMHCs were factors of 2-3 (factor of 6 for toluene) lower at Chebogue Point, Nova Scotia during summer 2004 (Millet et al., 2006) illustrating the closer proximity to anthropogenic sources at TF.

\subsection{Seasonal variation of anthropogenic $\mathrm{C}_{2}-\mathrm{C}_{8} \mathrm{NMHCs}$}

The $\mathrm{C}_{2}-\mathrm{C}_{6}$ alkanes, ethyne, toluene, and benzene exhibited reproducible seasonal trends where the longer lived compounds had higher mixing ratios and reached minimum annual mixing ratios later in the year. Ethane mixing ratios peaked in winter-early spring and then decreased until mid to late summer when minimum mixing ratios were observed (Fig. 3a). Mixing ratios of the $\mathrm{C}_{3}-\mathrm{C}_{6}$ alkanes, alkenes, ethyne, and aromatics began to decrease in mid to late winter and reached minimum levels $2-4$ months later (Fig. 3; Table 1). Ethene, ethyne, and benzene remained at their annual minimum mixing ratios from late spring to late summer (Fig. 3d). Despite its order of magnitude shorter lifetime, ethene mixing ratios were often similar to or higher than ethyne in summer, fall, and winter indicating the importance of ethene emissions in NH. The monthly mean and median propane, $\mathrm{i}$-butane, and $\mathrm{n}$-butane mixing ratios were lowest in late spring (May-June) followed by an increase in early summer before reaching a second minimum in late summer (Table 1). In comparison, minimum mixing ratios of the shorter-lived $\mathrm{C}_{5}-\mathrm{C}_{6}$ alkanes, propene, and toluene occurred earliest (April-May), increased in early summer, and then remained within a similar range through OctoberNovember (Fig. 3c, f; Table 1). The mean summer mixing ratios of propene, toluene, and the $\mathrm{C}_{5}-\mathrm{C}_{6}$ alkanes were $\sim 15-$ $90 \%$ higher than the April-May mean mixing ratios. These NMHCs react rapidly with $\mathrm{OH}$ (summer lifetime $<1.5$ days assuming $[\mathrm{OH}]=2 \times 10^{6}$ molecules $\mathrm{cm}^{-3}$ ), and thus would be expected to remain at minimum mixing ratios throughout the entire summer. The summer increase in mixing ratios is indicative of a strong influence from evaporative emissions on the NMHC distribution (discussed in more detail in Sect. 4).

On average, 1-butene, ethylbenzene, and xylenes $(m+p$ and o) were also highest in winter, lowest in early to mid spring, and increased in early summer (Fig. 3e-g, Table 1). Superimposed on the general alkene and $\mathrm{C}_{8}$ aromatic seasonal patterns were unique interannual trends reflecting varying sources or emission rates. For example, a higher and narrower range of propene $(\sim 50-80 \mathrm{pptv})$ and 1-butene $(\sim 8-$ 17 pptv) monthly mean and median mixing ratios were observed in spring 2006 through winter 2008 compared to the previous two years when distinct winter peaks and springsummer minimum mixing ratios occurred. Additionally, the highest monthly mean and median $\mathrm{m}+\mathrm{p}$-xylene and o-xylene mixing ratios of the entire four year study period $(\sim 25-40$ and 25-35 pptv, respectively), as well as the highest summer toluene (90-140 pptv) and ethylbenzene (14-22 pptv) mixing ratios, were observed in summer 2007 and elevated mixing ratios persisted through winter 2008.

\subsection{Influence of enhanced NMHC emissions on summer photochemistry}

The enhanced summer mixing ratios of reactive NMHCs will likely influence the ambient mixing ratios and regional budgets of secondary photochemical species, such as organic aerosols, OVOCs, and $\mathrm{O}_{3}$. NMHCs make variable contributions to the production of secondary species because of their different rates of reaction with $\mathrm{OH}$. The incremental reactivity (IR) is a method for determining the various ozone formation potentials (OFP) of VOCs and takes into consideration the different chemical reaction pathways following the initial reaction of the NMHC with $\mathrm{OH}$. The incremental reactivity is defined as the change in $\mathrm{O}_{3}$ resulting from the addition or subtraction of an increment of VOC to/from an airmass divided by the amount of VOC added or removed (Carter, 1994; Bowman and Seinfeld, 1995). An estimate of the maximum possible amount of $\mathrm{O}_{3}$ that could be formed resulting from the higher propene, $\mathrm{C}_{5}-\mathrm{C}_{6}$ alkane, and toluene in summer was made using the following equation: $\Delta \mathrm{O}_{3}=\Delta \mathrm{NMHC} \times$ MIR where $\triangle \mathrm{NMHC}=$ maximum 

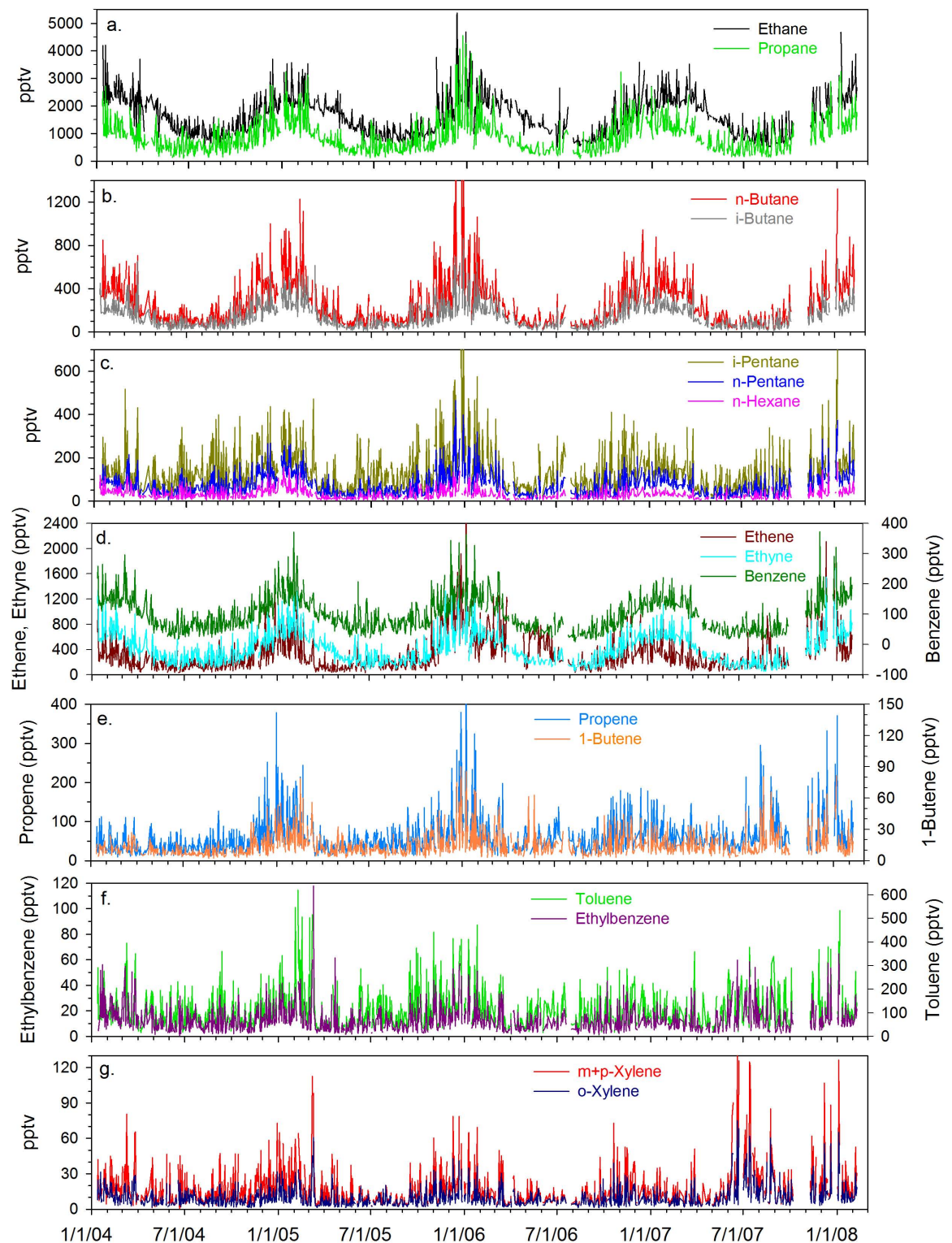

Fig. 3. Time series of NMHCs (pptv) at TF during January 2004-February 2008: (a) ethane, propane, (b) n-butane, i-butane, (c) i-pentane, n-pentane, n-hexane, (d) ethene, ethyne, benzene (note that the benzene axis is offset), (e) propene, 1-butene, (f) toluene, ethylbenzene, and (g) m+p-xylene, o-xylene.

summer mixing ratio - average spring mixing ratio and MIR is the maximum incremental reactivity factor (gram of $\mathrm{O}_{3}$ produced/additional gram of NMHC) (Carter, 1994, 2008). For these calculations, we are assuming that conditions are favorable for $\mathrm{O}_{3}$ production. The atmosphere over New England in summer is generally $\mathrm{NO}_{\mathrm{x}}$-limited because of the abundance of biogenic VOCs. Nonetheless, summer $\mathrm{NO}_{\mathrm{x}}$ mixing ratios at $\mathrm{TF}$ have been observed to range from $0.21-$ $17.5 \mathrm{ppbv}$ (average $2.3 \mathrm{ppbv}$ ) (Griffin et al., 2007). These $\mathrm{NO}_{\mathrm{x}}$ mixing ratios are sufficient for the $\mathrm{NO}+$ peroxy radical reaction to be preferred over peroxy radical self reactions (e.g., Flocke et al., 1991; Roberts et al., 1998). These calculations indicate that $0.5-2.4 \mathrm{ppbv}, 0.46-0.65 \mathrm{ppbv}, 0.15-$
0.24 ppbv, 0.08-0.1 ppbv, and 1.2-2.3 ppbv (total range 2.4$5.7 \mathrm{ppbv}$ ) of additional $\mathrm{O}_{3}$ could be formed as a result of the enhanced propene, i-pentane, n-pentane, n-hexane, and toluene mixing ratios, respectively, in summer at TF. In comparison, the $24 \mathrm{~h}$ mean $\mathrm{O}_{3}$ mixing ratios at $\mathrm{TF}$ are $\sim 30 \mathrm{ppbv}$ in summer (Mao and Talbot, 2004a; Talbot et al., 2005). These results are not absolute levels of $\mathrm{O}_{3}$ that will be produced because the MIR factors were derived for conditions that do not necessarily reflect New England (Carter, 1994). Nonetheless, these results are intended to illustrate the potentially significant impact of the enhanced summer mixing ratios of reactive NMHCs on the ozone formation potential in this region. 

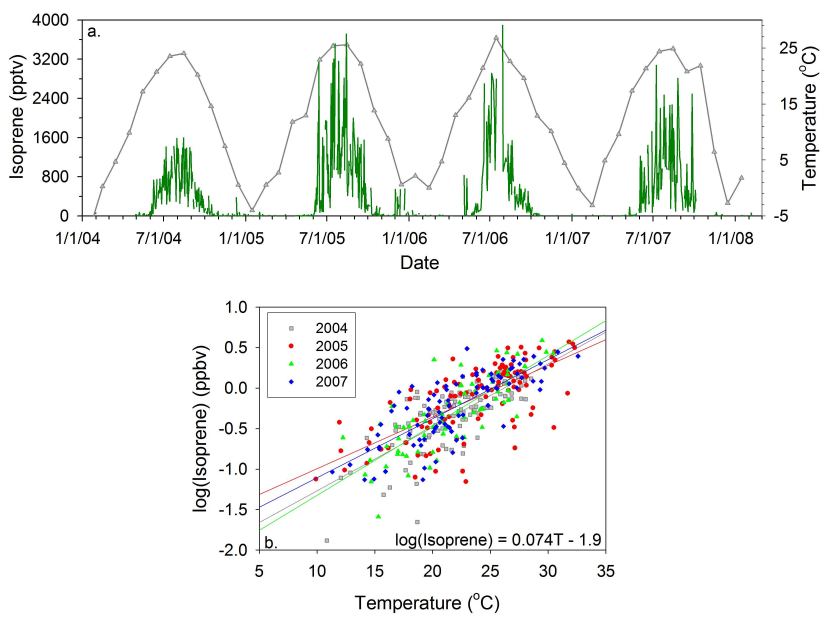

Fig. 4. (a) Time series of isoprene (pptv) (green line) and the monthly mean temperature $\left({ }^{\circ} \mathrm{C}\right.$ ) (gray line) at TF during January 2004-February 2008. (b) Correlation between $\log$ (isoprene) (in ppbv) and the hourly average temperature (corresponding to the hour the canister sample was collected) during June-September of 2004, 2005, 2006, and 2007.

\subsection{Isoprene}

Isoprene is the only NMHC discussed in this work with a predominantly biogenic origin (deciduous plants and trees) (e.g., Guenther et al., 1995). Isoprene mixing ratios rapidly increased in the beginning of June, remained high through August, and gradually decreased in September-October of each year (Fig. 4a, Table 1). In July-August 2005, 2006, and 2007, isoprene was the most abundant NMHC (monthly mean mixing ratios $=1000-2100 \mathrm{pptv}$ ) illustrating the importance of biogenic emissions in this region. In comparison, mean ethane (the longest lived NMHC) mixing ratios were $\sim 800-1250$ pptv. Isoprene was positively correlated with the ambient temperature during each summer. The relationship can be expressed as $\log$ (isoprene $)=0.074 \mathrm{~T}-1.9\left(r^{2}=0.57\right)$ for all of the available June-September data (Fig. $4 \mathrm{~b})\left(T\right.$ in ${ }^{\circ} \mathrm{C}$ corresponding to the hour the sample was collected). The highest isoprene mixing ratios ( $>3 \mathrm{ppbv}$ ) were observed in the warmest summers (2005 and 2006) while the lowest $(<1600 \mathrm{pptv})$ mixing ratios occurred during the coolest summer (2004). The temperature dependence of isoprene was nearly the same each summer, on sunny/clear days, and on cloudy/rainy days. Furthermore, this relationship is consistent with previous studies (e.g., Fehsenfeld et al., 1992; Jobson et al., 1994; Goldan et al., 1995; Gong and Demerjian, 1997; Hagerman et al., 1997; Kang et al., 2001) indicating a similar temperature dependence of ambient isoprene mixing ratios at various North American sites.
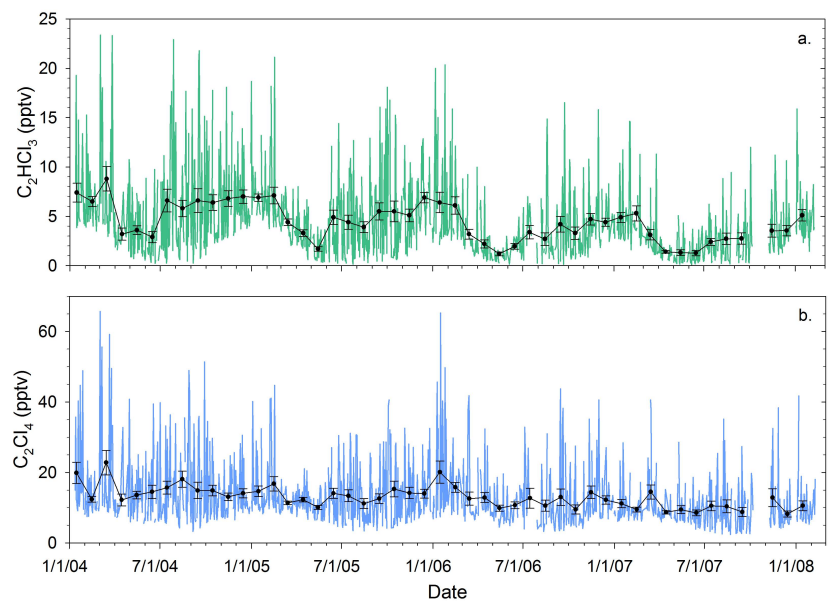

Fig. 5. Time series of (a) $\mathrm{C}_{2} \mathrm{HCl}_{3}$ and (b) $\mathrm{C}_{2} \mathrm{Cl}_{4}$ (pptv) at TF during January 2004-February 2008. Black line and circles are the monthly mean \pm standard error mixing ratios.

\subsection{Halocarbons}

Trichloroethene and tetrachloroethene are primarily used as dry cleaning and degreasing solvents and are thus tracers of industrial sources (e.g., Wang et al., 1995; McCulloch and Midgley, 1996). It is necessary to monitor the atmospheric trends of $\mathrm{C}_{2} \mathrm{HCl}_{3}$ and $\mathrm{C}_{2} \mathrm{Cl}_{4}$ because they are used as replacements for CFCs and in the production of HFCs and HCFCs and because they are classified as toxic air pollutants and are regulated by the EPA (US EPA, 2007). A wide range of $\mathrm{C}_{2} \mathrm{Cl}_{4}(3-65 \mathrm{pptv})$ and $\mathrm{C}_{2} \mathrm{HCl}_{3}(<1-23 \mathrm{pptv})$ mixing ratios were observed at $\mathrm{TF}$ (Fig. 5). The shorterlived (days-weeks) $\mathrm{C}_{2} \mathrm{HCl}_{3}$ had a similar seasonal variation as the NMHCs with a winter maximum (monthly mean mixing ratios $=5-8 \mathrm{pptv})$, late spring minimum $(1-2 \mathrm{pptv})$, and an early summer increase ( $2-5 \mathrm{pptv})$. Similar to propene, the $\mathrm{C}_{5}-\mathrm{C}_{6}$ alkanes, and toluene, the mean mixing ratios in summer were $50-75 \%$ higher than in spring illustrating that evaporative emissions of $\mathrm{C}_{2} \mathrm{HCl}_{3}$ are important to its atmospheric distribution in this region. In contrast, the monthly mean mixing ratios of the longer-lived (months) $\mathrm{C}_{2} \mathrm{Cl}_{4}$ were fairly uniform. A seasonal variation was apparent in the $\mathrm{C}_{2} \mathrm{Cl}_{4}$ background (monthly 10th percentile) mixing ratios which were highest in winter (8-9 pptv) and lowest in late summer (3-5 pptv).

The monthly mean halocarbon mixing ratios at $\mathrm{TF}$ are higher than observed at remote sites, such as Mace Head, Ireland (Simmonds et al., 2006), along the US west coast (Simpson et al., 2004), NOAA CMDL sites (Thompson et al., 2004), Chebogue Point, Nova Scotia (Millet et al., 2006), and over the North Atlantic Ocean (Dimmer et al., 2001), reflecting the closer proximity to industrial sources and their continued use in North America, but are lower than observed in heavily urbanized areas, such as Pittsburgh, PA (Millet et 
al., 2005), Houston, TX (Gilman et al., 2009), and Mexico City, Mexico (Velasco et al., 2007). The $\mathrm{C}_{2} \mathrm{Cl}_{4}$ mixing ratios at TF are similar to background levels in Massachusetts during 1996-1999 (Kleiman and Prinn, 2000; Barnes et al., 2003) which suggests that $\mathrm{C}_{2} \mathrm{Cl}_{4}$ emission rates in more populated areas in the US did not change considerably between the late 1990's and 2004. However, we have observed a decrease in the magnitude of peak mixing ratios, and in the annual mean, median, and background mixing ratios throughout 2004-2008 at TF (Fig. 5, Table 2). More specifically, the background mixing ratios of $\mathrm{C}_{2} \mathrm{Cl}_{4}$ and $\mathrm{C}_{2} \mathrm{HCl}_{3}$ were $30 \%$ and $65 \%$ lower, respectively, in 2007 than in 2004. According to the EPA 2008 Toxics Release Inventory (www.epa.gov/tri), $\mathrm{C}_{2} \mathrm{HCl}_{3}$ emission reductions were about a factor of two larger than $\mathrm{C}_{2} \mathrm{Cl}_{4}$ over the same time period.

An estimate of the rate of decrease in atmospheric mixing ratios of both halocarbons was made using the annual statistics in order to minimize the influence of the seasonal variation in $\mathrm{C}_{2} \mathrm{HCl}_{3}$ and in background $\mathrm{C}_{2} \mathrm{Cl}_{4}$. The linear regression through the annual background mixing ratios gave decrease rates ( \pm standard deviation) of $0.73 \pm 0.24$ and $0.27 \pm 0.05 \mathrm{pptv} / \mathrm{year}$ for $\mathrm{C}_{2} \mathrm{Cl}_{4}$ and $\mathrm{C}_{2} \mathrm{HCl}_{3}$, respectively (Table 2). In comparison, $\mathrm{C}_{2} \mathrm{Cl}_{4}$ decrease rates (pptv/year) were estimated to be $1.0\left(\mathrm{C}_{2} \mathrm{HCl}_{3}=0.1\right)$ in $1991-1996$ at Alert, Canada (Gautrois et al., 2003), 0.6-1.2 during 19941997 in the continental US (Hurst et al., 1998), 0.1-0.4 throughout 1989-2002 along the North American west coast (Simpson et al., 2004), $0.18\left(\mathrm{C}_{2} \mathrm{HCl}_{3}=0.01\right)$ during July 2000-December 2004 at Mace Head, Ireland (Simmonds et al., 2006), and 5\% per year in 1995-2003 based on analysis of EPA and NOAA CMDL data at remote North American sites (McCarthy et al., 2006). It must be kept in mind that the trends observed at TF and other locations represent different time periods, emission rates, and industrial regulations. Nonetheless, our results indicate that the amounts of $\mathrm{C}_{2} \mathrm{Cl}_{4}$ and $\mathrm{C}_{2} \mathrm{HCl}_{3}$ being transported from the northeastern US to the North Atlantic are decreasing.

\section{NMHC source identification}

\subsection{Comparison with tracers and source signatures}

The major sources of ethyne, benzene, carbon monoxide (CO), and alkenes are incomplete combustion of fossil fuels, biomass burning, and vehicle exhaust emissions (e.g., Harley et al., 1992, 2001; McLaren et al., 1996; Choi and Ehrman, 2004). The oxidation of VOCs is also a potential secondary source of $\mathrm{CO}$, particularly in summer when biogenic NMHC mixing ratios are high (Sect. 3.4) (Hudman et al., 2008). Studies focused on the northeast US during summer 2004 found that observed CO mixing ratios could largely be explained by primary urban/industrial and biomass burning sources (Warneke et al., 2006; Griffin et al., 2007). Thus, in our analysis, we neglect the possible secondary
Table 2. Annual $\mathrm{C}_{2} \mathrm{HCl}_{3}$ and $\mathrm{C}_{2} \mathrm{Cl}_{4}$ statistics (pptv) for 20042008, and the rate of decrease (pptv/year) in the annual background mixing ratios \pm standard deviation (SD). $N$ is the number of samples. Background is the 10th percentile for the entire year.

\begin{tabular}{lrr}
\hline & $\mathrm{C}_{2} \mathrm{HCl}_{3}$ & $\mathrm{C}_{2} \mathrm{Cl}_{4}$ \\
\hline 2004 & & \\
Mean (SD) & $6.0(4.7)$ & $15.8(10.5)$ \\
Median (N) & $4.6(277)$ & $12.3(277)$ \\
Background & 1.3 & 6.7 \\
Range & $0.25-23.4$ & $3.3-65.7$ \\
2005 & & \\
Mean (SD) & $5.0(3.7)$ & $13.3(7.6)$ \\
Median $(N)$ & $4.5(323)$ & $11.0(324)$ \\
Background & 0.9 & 6.2 \\
Range & $0.16-21.1$ & $3.4-44.7$ \\
2006 & & \\
Mean (SD) & $4.0(3.6)$ & $13.1(9.2)$ \\
Median $(N)$ & $2.9(264)$ & $9.6(270)$ \\
Background & 0.7 & 5.7 \\
Range & $0.14-20.3$ & $3.3-65.3$ \\
2007 & & \\
Mean (SD) & $3.0(2.6)$ & $10.5(6.5)$ \\
Median $(N)$ & $2.5(240)$ & $8.6(244)$ \\
Background & 0.5 & 4.5 \\
Range & $0.12-14.6$ & $2.4-40.6$ \\
pptv/year (SD) & $-0.27 \pm 0.05$ & $-0.73 \pm 0.24$ \\
$r^{2}$ & 0.99 & 0.95 \\
\hline
\end{tabular}

contribution to $\mathrm{CO}$. Ethyne and $\mathrm{CO}$ were fairly well correlated at $\mathrm{TF}\left(r^{2}=0.5-0.9\right)$ demonstrating a year-round impact from combustion emissions (Fig. 6a). The correlations between alkenes and tracers for combustion (ethyne), liquefied petroleum gas (LPG) (propane), and fuel evaporation (i-pentane) were strongest in winter and showed considerable scatter in the other seasons. The short-lived alkenes had presumably undergone mixing and oxidative removal during transport resulting in weaker correlations in spring, summer, and fall. Based on the winter measurements, the ethene and propene correlation slopes with ethyne ( 1.2 and 0.21 , respectively) were similar to light duty gasoline and vehicle exhaust emission ratios (0.9-1.7 and 0.1-0.5, respectively) (Conner et al., 1995; Watson et al., 2001; Choi and Ehrman, 2004; McGaughey et al., 2004) suggesting that vehicular emissions were the dominant source of these alkenes. Propene and 1butene were well correlated throughout the majority of the study period reflecting a common source (Fig. 6b). The correlation coefficients between ethyne and the alkanes, benzene, and toluene were fairly variable within each season and year $\left(r^{2}=0.4-0.9\right)$, but overall suggest that combustion sources were collocated with or were the same as the alkane and aromatic sources. 

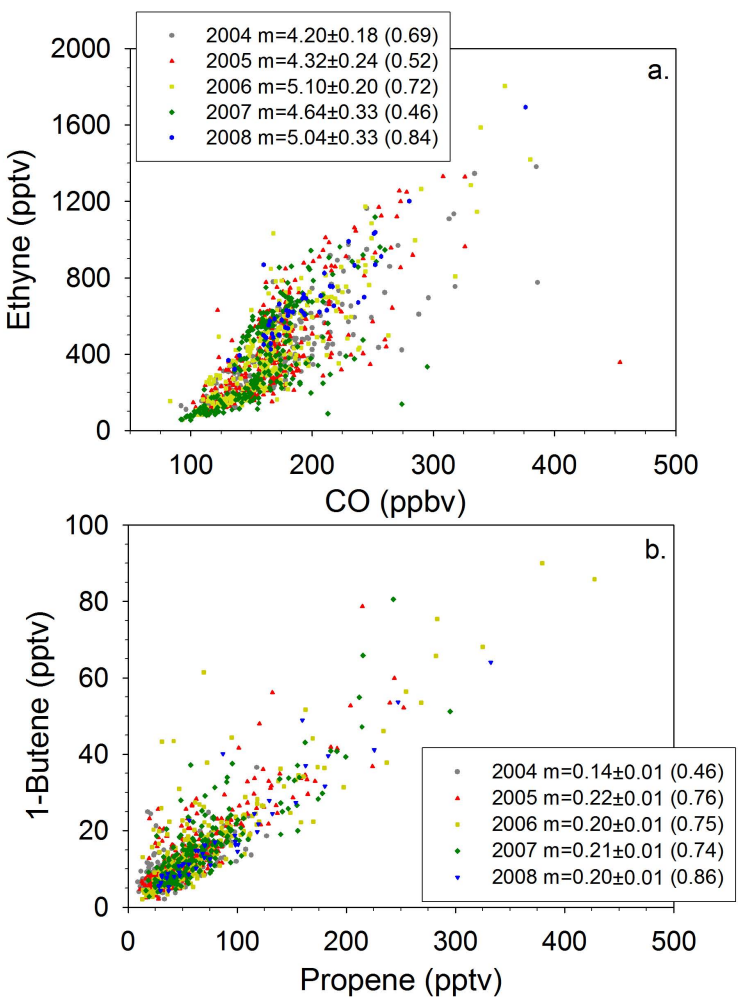

Fig. 6. Correlations ( $m=$ slope \pm standard error $\left(r^{2}\right)$ ) between (a) $\mathrm{CO}(\mathrm{ppbv})$ and ethyne and (b) propene and 1-butene for each year (2004, 2005, 2006, 2007, 2008).

The $\mathrm{C}_{3}-\mathrm{C}_{6}$ alkanes were well correlated with each other $\left(r^{2}=0.6-0.9\right)$. The slopes of the correlation between propane and n-butane (2.2-2.7, Fig. 7a) and i-butane (3.8-5.5, not shown) agree with LPG emission ratios (2-4 and 3-7, respectively) (e.g., Scheff and Wadden, 1993; Blake and Rowland, 1995; Goldan et al., 1995; Chen et al., 2001; Fujita, 2001; Watson et al., 2001; Mukerjee et al., 2004; Barletta et al., 2008) indicating that LPG emissions are widespread and prevalent in New England. Moreover, the i-butane/nbutane slope (0.49-0.56, Fig. 7b) was within the range of reported emission ratios from several sources, including urban/vehicular exhaust ( $\sim 0.2-0.3)$, LPG $(0.46)$, and natural gas $(\sim 0.6$ to $>1)$ (B. Sive, unpublished data; Jobson et al., 1998, 2004; Goldan et al., 2000; Fujita, 2001; Watson et al., 2001; Barletta et al., 2002; Choi and Ehrman, 2004; Velasco et al., 2007). Additionally, the slope of the correlation between i-pentane and n-pentane (range for each season each year=1.5-2.6) (Fig. 7c) was within the range of reported emission ratios for vehicle exhaust and tunnel studies $(\sim 2.2-$ 3.8), liquid gasoline (1.5-3), and fuel evaporation (1.8-4.6) (Conner et al., 1995; Harley et al., 2001; Watson et al., 2001; Jobson et al., 2004; McCaughey et al., 2004; Lough et al., 2005; Velasco et al., 2007). Overall, these results suggest that a uniform mix of emissions from numerous alkane sources is observed at TF.
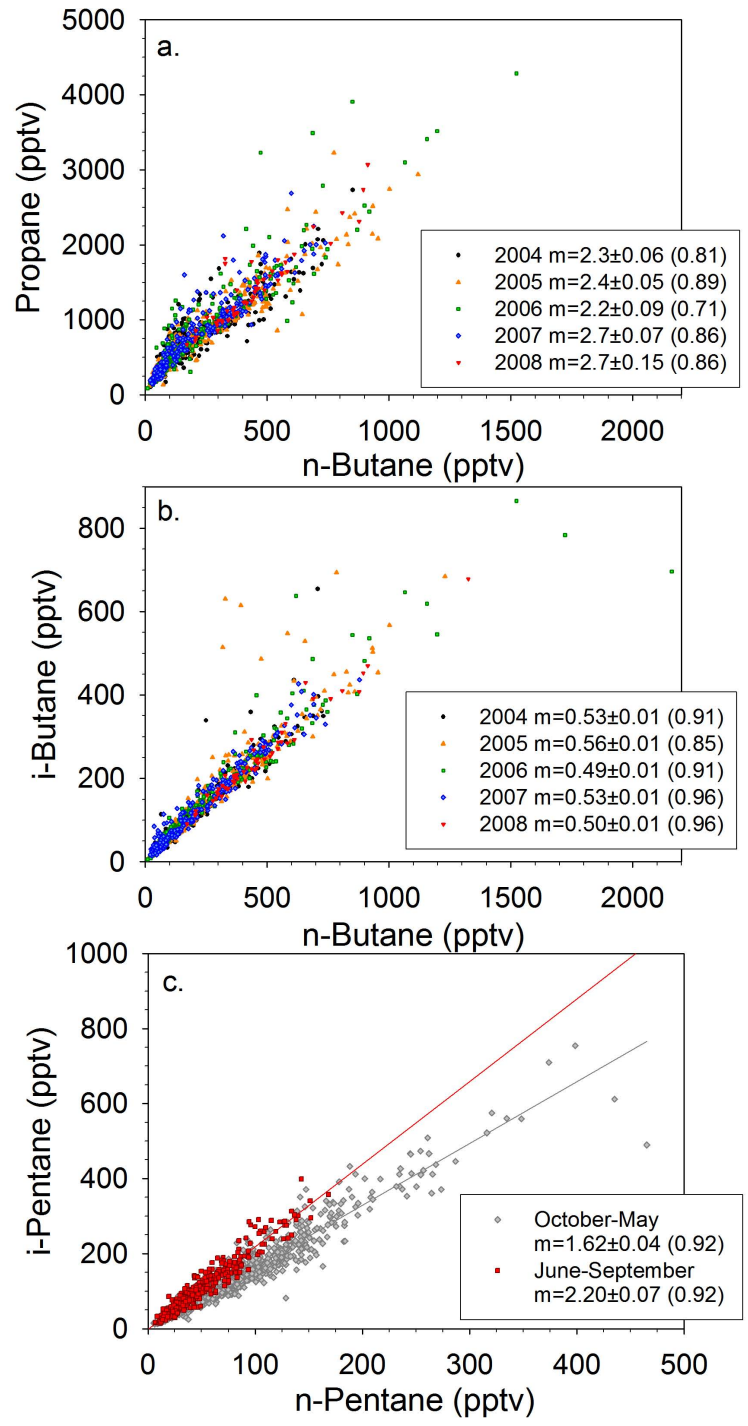

Fig. 7. Correlation ( $m=$ slope \pm standard error $\left.\left(r^{2}\right)\right)$ of $n$-butane with (a) propane and (b) i-butane for each year. (c) Correlation between n-pentane and i-pentane. Gray diamonds are all of the samples collected in October-May of 2004-2008. Red squares are all of the samples collected in June-September of 2004-2007.

The i-pentane/n-pentane correlation slope was noticeably higher in the warmer months each year (June-September slope $=2.2$; October-May slope $=1.6$, Fig. 7c) which likely reflects enhanced evaporative emissions of i-pentane (e.g., Rubin et al., 2006). Additionally, the correlation slopes between the $\mathrm{C}_{5}-\mathrm{C}_{6}$ alkanes and butanes were factors of $\sim 0.5-2$ higher in summer. Gasoline retailers in New England are required to sell reformulated gasoline with a lower Reid vapor pressure (RVP) in order to reduce emissions of highly volatile NMHCs in the summer (US EPA, 2003, 2008). Our measurements demonstrate that fuel evaporation and headspace vapor emissions of the $\mathrm{C}_{5}-\mathrm{C}_{6}$ alkanes were still strong enough to partially counteract $\mathrm{OH}$ chemistry throughout the entire 
summer each year. These relationships will continue to be monitored in order to identify and evaluate any potential impacts of the switch to using gasoline containing $10 \%$ ethanol (E10) in 2007 (www.des.nh.gov) on the ambient distributions of NMHCs in New England.

The $\mathrm{C}_{7}-\mathrm{C}_{8}$ aromatics were well correlated illustrating their common sources. The toluene/ethylbenzene correlation slope was in good agreement with vehicular and urban emission ratios (Fig. 8a) (e.g., Parrish et al., 1998; Monod et al., 2001). The o-xylene/m+p-xylene correlation slope $(0.44-0.55$, Fig. $8 b)$ was slightly higher, and the $\mathrm{m}+\mathrm{p}$-xylene/ethylbenzene (1.1-1.9, Fig. 8c) and oxylene/ethylbenzene (0.53-1.1, not shown) slopes were lower than industrial/urban, gasoline, fuel evaporation, and vehicle exhaust emission ratios $(\sim 0.36-0.4,2.2-4.6$, and 1.2-1.8, respectively) (Conner et al., 1995; Kirchstetter et al., 1996; Sagebiel et al., 1996; Rogak et al., 1998; Monod et al., 2001; Watson et al., 2001; Choi and Ehrman, 2004; Jobson et al., 2004; Velasco et al., 2007). The differences between the emission and ambient $\mathrm{C}_{8}$ aromatic ratios likely reflect the preferential loss of the xylenes during air mass transport because of their greater reactivity.

\subsection{Ambient ratios: compounds with similar lifetimes}

Information on the relative impact of various sources in a region can be obtained by comparing the ambient ratio of two compounds that have similar rates of reaction with $\mathrm{OH}$ but different sources (e.g., Klemp et al., 1997; Jobson et al., 1999; Goldan et al., 2000). The ratio should reflect the integration of several factors, such as air mass mixing and dilution, new emission inputs, and oxidative removal, because neither compound will be removed preferentially during transport. Thus, on average, the ratio can be assumed to remain fairly constant and approximately equal to the emission ratio (Parrish et al., 1998). For example, propane, ethyne, and benzene have similar lifetimes ( $<30 \%$ difference in $k_{\mathrm{OH}}$ ) (Atkinson et al., 2006), but these NMHCs are tracers of different sources. The propane/ethyne, propane/benzene, and benzene/ethyne vehicular exhaust and whole gasoline emission ratios are typically $<1$ while ratios from natural gas, LPG, or gasoline vapor are $\geq \sim 1$ (e.g., Conner et al., 1995; Fujita et al., 1995; Fujita, 2001; Mukund et al., 1996; Lawrimore et al., 1997; Watson et al., 2001; Choi and Ehrman, 2004; Mukerjee et al., 2004; White et al., 2008). Throughout 2004-2008, the propane/ethyne (Fig. 9a) and propane/benzene ratios ranged from $1-5$ and $3-25$, respectively, demonstrating the stronger influence of natural gas or LPG relative to incomplete combustion as a source of propane throughout the entire year. This corroborates previous work at $\mathrm{TF}$ and Appledore Island, Maine $(10 \mathrm{~km}$ off the $\mathrm{NH}$ coast) during summer 2004 which concluded that LPG was the dominant source of propane throughout the entire day in southern $\mathrm{NH}$ (White et al., 2008). Furthermore, Goldan et al. (2004) illustrated that the relationship between
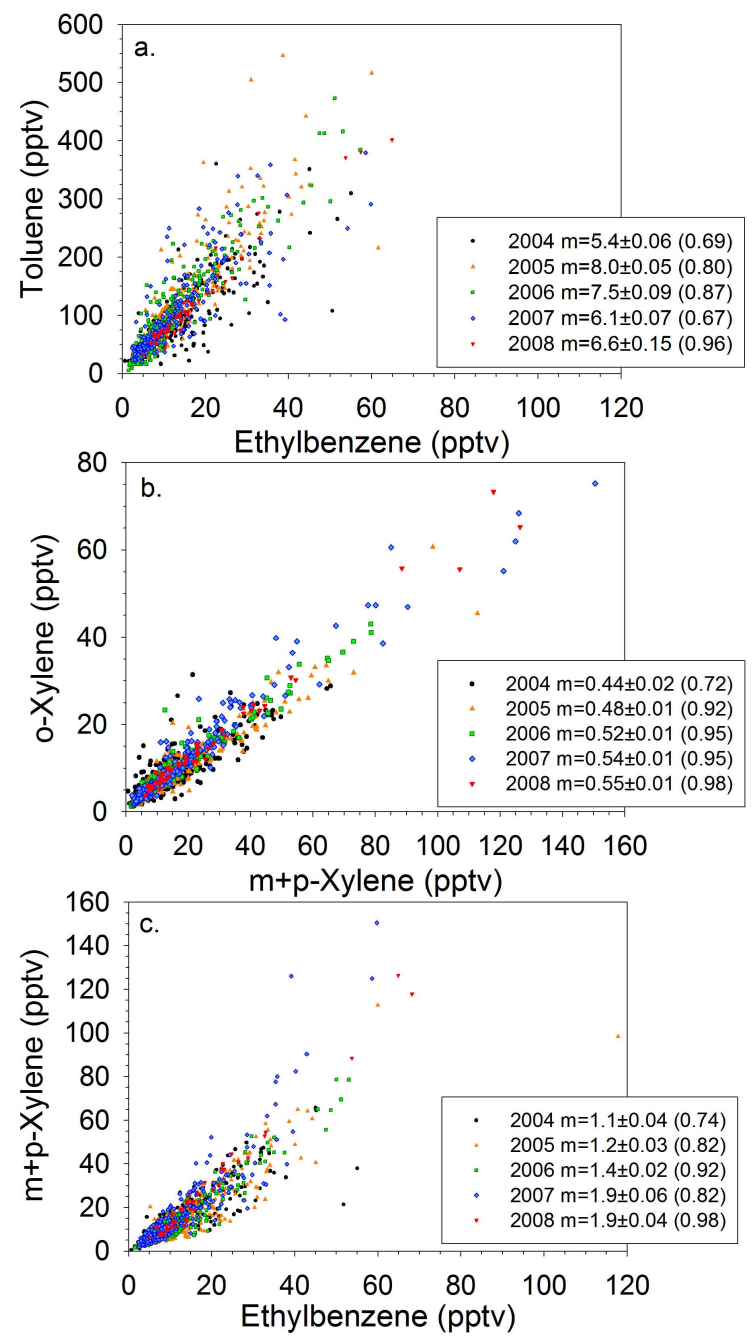

Fig. 8. Correlations ( $m=$ slope \pm standard error $\left(r^{2}\right)$ ) between (a) toluene and ethylbenzene, (b) o-xylene and $\mathrm{m}+\mathrm{p}$-xylene, and (c) $\mathrm{m}+\mathrm{p}$-xylene and ethylbenzene for each year.

propane and benzene was unique to the northeast US based on measurements made off the New England coast during the NEAQS 2002 campaign and suggested that this is indicative of a non-vehicular source of propane. This supports our observations of a significant influence from LPG use and/or leakage at $\mathrm{TF}$.

The slope of the benzene vs. ethyne correlation was the same in each season of every year (slope of all data $=0.21$, $r^{2}=0.91$ ) (Fig. 9b). This ratio value is indicative of a vehicular source and is consistent with observations of ambient benzene/ethyne ratios measured during several spring-summer field campaigns conducted throughout the US (Fortin et al., 2005; Harley et al., 2006; Parrish, 2006; Sistla and Aleksic, 2007; Warneke et al., 2007) and in major cities (Parrish et al., 2009). The strong correlations between propane and ethyne (Fig. 9a), propane and benzene $\left(r^{2}=0.71-0.76\right.$, not shown), and benzene and ethyne (Fig. 9b) suggest that emissions from 


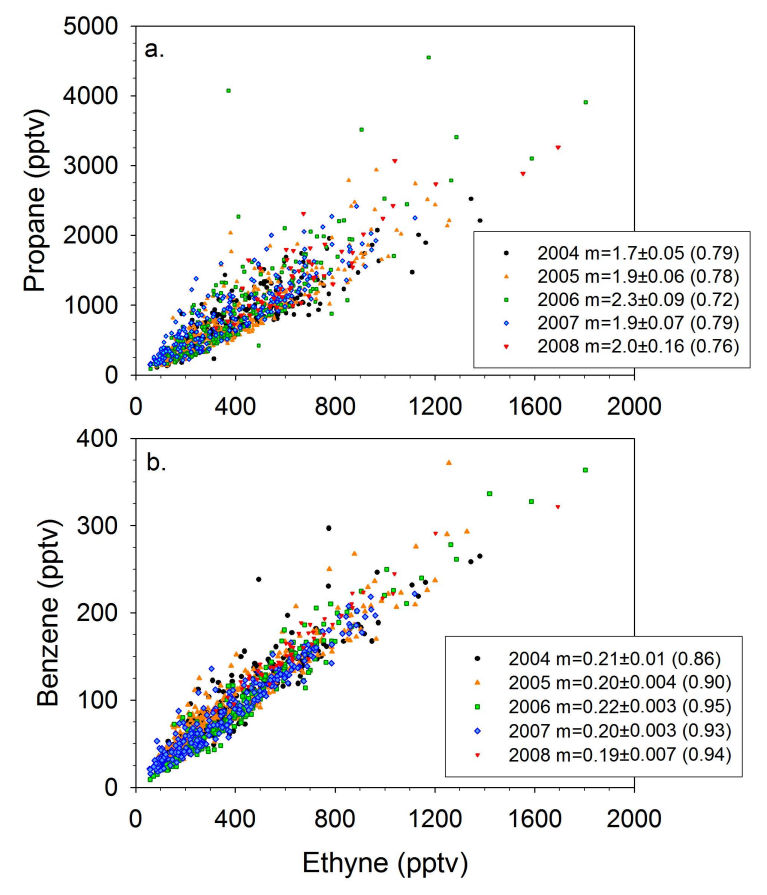

Fig. 9. Correlation ( $m=$ slope \pm standard error $\left(r^{2}\right)$ ) of ethyne with (a) propane and (b) benzene for each year.

natural gas, petroleum, and fossil fuel/incomplete combustion (e.g., vehicles) sources were concurrent and/or collocated. Moreover, this illustrates a pervasive and continuous influence of emissions from several anthropogenic sources on the chemical composition of air masses observed at TF.

\subsection{Ambient ratios: compounds with different lifetimes}

Ambient ratios between compounds with different rates of reaction with $\mathrm{OH}$ and with well characterized sources and sinks are frequently used to estimate the relative photochemical age of air masses, transport times and distances, or $\mathrm{OH}$ concentrations (e.g., Jobson et al., 1994; McKeen et al., 1996; Parrish et al., 1998; Smyth et al., 1999; Dimmer et al., 2001; Kleinman et al., 2003; Russo et al., 2003). A fundamental drawback to estimating air mass processing times using ambient ratios is a lack of information on seasonal variations in sources, especially when analyzing data from short-term field campaigns. Analysis of the long-term measurements from $\mathrm{TF}$ provided a unique perspective on the interrelationships between seasonal variations in sources and chemical processing in this region.

Four common ratios with the shorter-lived compound in the numerator are ethyne/CO, propane/ethane, toluene/benzene, and $\mathrm{C}_{2} \mathrm{HCl}_{3} / \mathrm{C}_{2} \mathrm{Cl}_{4}$ (Fig. 10). The general behavior of these ratios can be predicted based on the differential removal of the compounds in each ratio. For example, if reaction with $\mathrm{OH}$ was the only factor influencing the seasonality in mixing ratios, a decrease in ratio values from

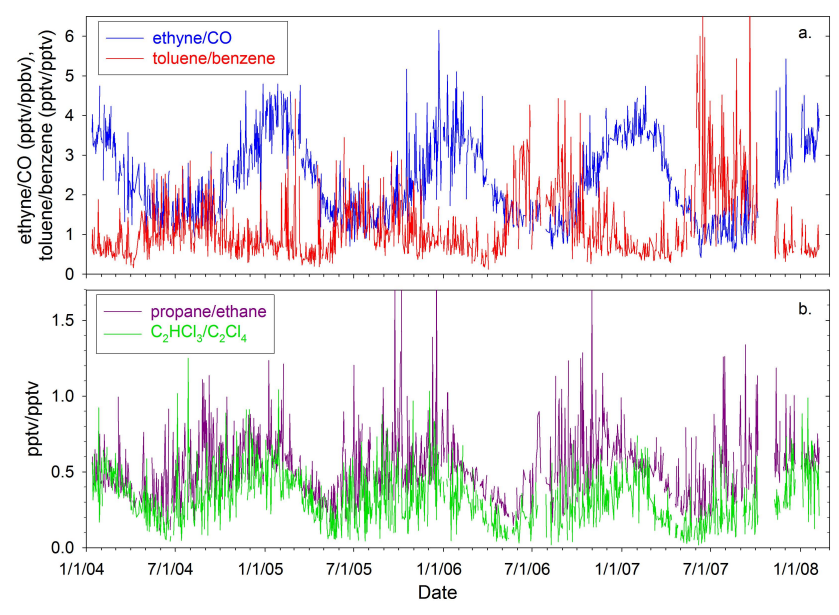

Fig. 10. Time series of the (a) ethyne/CO (pptv/ppbv) and toluene/benzene ratios and (b) propane/ethane and $\mathrm{C}_{2} \mathrm{HCl}_{3} / \mathrm{C}_{2} \mathrm{Cl}_{4}$ ratios during January 2004-February 2008.

winter to summer would be expected to occur concurrently with the increase in atmospheric $\mathrm{OH}$ concentrations because the shorter-lived compound is removed preferentially. The ethyne/CO ratio trend reflects the seasonal variation in $\mathrm{OH}$ concentrations with higher winter ratios (4-5 pptv/ppbv) indicating less processed emissions and low summer ratios (1-2 pptv/ppbv) reflecting more processed air masses (Fig. 10a). The propane/ethane and $\mathrm{C}_{2} \mathrm{HCl}_{3} / \mathrm{C}_{2} \mathrm{Cl}_{4}$ ratios tracked each other very well, and the temporal variation of both ratios resembled the ethyne/CO ratio with maximum values in winter and minimum values in late spring-summer (Fig. 10b). However, the propane/ethane and $\mathrm{C}_{2} \mathrm{HCl}_{3} / \mathrm{C}_{2} \mathrm{Cl}_{4}$ ratios increased throughout summer and fall which likely reflects the similar lifetimes and seasonal variation of propane and $\mathrm{C}_{2} \mathrm{HCl}_{3}$ combined with the mid to late summer minimum ethane and $\mathrm{C}_{2} \mathrm{Cl}_{4}$ mixing ratios.

The seasonal variation of the toluene/benzene ratio was opposite of the ethyne/CO, propane/ethane, and $\mathrm{C}_{2} \mathrm{HCl}_{3} / \mathrm{C}_{2} \mathrm{Cl}_{4}$ ratio behavior, and thus contrary to the expected photochemical trend (Fig. 10a). The toluene/benzene ratio was lowest in winter-spring $(\sim 0.5-1.5)$ and highest in summer-fall (0.5-7). These ratio values are comparable to ambient ratios (1-5) observed in numerous continental/urban areas (e.g., Parrish et al., 1998; Monod et al., 2001). However, the fact that the ratio increases in the summer is indicative of an additional source or enhanced emissions of toluene in this region. White et al. (2009) illustrated that the anomalous toluene behavior at TF could not be fully explained by fuel evaporation and industrial emissions and provided evidence for a biogenic contribution to the summer toluene enhancements. It was also noted that the toluene enhancements were larger with each successive year (White et al., 2009). This trend continued into 2007 when the highest toluene/benzene ratios (mean=2.1) were observed (Fig. 10a). 
This analysis provides a clear illustration for the necessity of characterizing VOC sources in individual regions. As recently discussed by Schnitzhofer et al. (2008), these results have important implications because numerous studies have used the toluene/benzene ratio to estimate photochemical air mass ages (e.g., Roberts et al., 1984; Gong and Demerjian, 1997; Kang et al., 2001; de Gouw et al., 2005; Warneke et al., 2007) or to distinguish between industrial, evaporative, and exhaust emission sources (e.g., Barletta et al., 2008). The TF measurements demonstrate that the toluene/benzene ratio may not be appropriate for estimating relative air mass ages in this region because variations in the ratio values reflect both chemical processing and additional toluene emissions. An additional source of toluene in this region causes the initial toluene/benzene emission ratio used in the processing time calculations to be erroneously high leading to overestimated photochemical air mass ages and transport distances.

\section{Emission rates of NMHCs}

\subsection{Emission rates estimated from observations at TF}

Emission rates of speciated VOCs based on ambient measurements are needed for developing regional budgets, implementing effective control strategies for reducing emissions of photochemical smog precursors and toxic compounds, and evaluating emission inventories and air quality models. Estimates of emission rates are limited and are primarily reported on global scales (e.g., Boissard et al., 1996; Gupta et al., 1998) or in urban areas during specific campaigns (e.g., Blake and Rowland, 1995; Chen et al., 2001, Velasco et al., 2005). Additionally, emissions for individual VOCs are usually lumped into specific classes (i.e., alkane, alkene, aromatic, biogenic). Major reasons for the lack of information on regional VOC emission rates include the complications involved with differentiating between local, regional, and distant sources and the scarcity of long-term continuous measurements. In order to minimize the complications associated with air mass transport, we focus on (1) winter measurements because the $\mathrm{C}_{2}-\mathrm{C}_{8} \mathrm{NMHC}$ lifetimes are longer than regional transport and mixing timescales at this time of year and (2) nighttime data when it has been determined that mixing is minimal. Under these conditions, we can assume that a change in NMHC mixing ratios reflects local sources or sinks. In contrast, the daily canister samples are representative of daytime conditions when mixing and transport may be occurring and can be assumed to reflect sources from a larger area. Thus, emission rates of NMHCs were calculated in two steps.

First, we estimated emission rates of NMHCs using hourly measurements from the automated in situ GC system at TF during December 2005-January 2006. We followed a simple box model approach which has been effectively used in previous studies to calculate emission and removal rates of trace gases in this region (i.e., Talbot et al., 2005; Zhou et al., 2005; Sive et al., 2007; White et al., 2008; Russo et al., 2010). This method uses measurements made on nights with low wind speeds and when a stable inversion layer has developed because under these conditions, the exchange of air between the nocturnal boundary layer (NBL) and the residual layer above is limited (e.g., Hastie et al., 1993; Gusten et al., 1998; Talbot et al., 2005). Therefore, advection and vertical mixing of air masses can be neglected. Two criteria were used for identifying nights when a stable inversion layer developed: (1) wind speeds $<1 \mathrm{~m} / \mathrm{s}$ and (2) $\mathrm{O}_{3} \leq 5 \mathrm{ppbv}$. The two criteria conditions were met on several nights between approximately midnight and 05:00 with concurrent increases in NMHC mixing ratios. Emission rates $\left(\mathrm{ER}_{\mathrm{GC}}\right)$ were calculated by multiplying the slope of the linear regression between the change in hourly average concentrations $\left(d C\right.$ in molecules $\left.\mathrm{cm}^{-3}\right)$ per unit time $(d t=5 \mathrm{~h})$ by the boundary layer height:

$\mathrm{ER}_{\mathrm{GC}}=\left[\frac{d C}{d t}\right] \cdot H$

Stable nocturnal boundary layer heights typically range from $\sim 50-200 \mathrm{~m}$ at midlatitude continental locations (e.g., Hastie et al., 1993; Gusten et al., 1998; McKendry and Lundgren, 2000; White et al., 2003); thus we chose $125 \mathrm{~m}$ as a representative value for the TF site (e.g., Talbot et al., 2005; Sive et al., 2007; Mao et al., 2008; White et al., 2008; Zhou et al., 2005). If we use $H=50 \mathrm{~m}$ or $200 \mathrm{~m}$, our emission rate estimates discussed below vary by $\pm 60 \%$. It must be kept in mind that the resulting emission rate estimates are directly proportional to the boundary layer height which varies with meteorological conditions, time of day, and season (Talbot et al., 2005).

In the second step, emission rates $\left(\mathrm{ER}_{\mathrm{DC}}\right)$ were calculated by multiplying the emission ratio for each compound from the daily canister samples by the emission rate of a reference compound (Eq. 2):

$\mathrm{ER}_{\mathrm{DC}}=\left(\frac{\mathrm{NMHC}}{\text { Ethyne }}\right) \cdot \mathrm{ER}_{\mathrm{GC} \_ \text {Ethyne }}$

Ethyne was used as the reference compound because of its relatively long lifetime and because its major source (combustion) is well known (e.g., Conner et al., 1995; Goldstein et al., 1995; de Gouw et al., 2005; Lee et al., 2006). Emission ratios using the winter 2006 daily canister data were determined from the slope of the correlation between a specific NMHC and ethyne (NMHC/ethyne). A comparison between the winter 2006 data from the automated in situ GC and the canister samples demonstrated that the mixing ratios agreed well $\left( \pm 10 \%, r^{2}=0.82-0.94\right.$; orthogonal distance regression) and that the results from the two instruments can be meaningfully compared (Fig. 11). The correlations are based on comparing the TF GC sample corresponding most closely to the time the canister was collected. These times agreed within less than one hour. The canister and GC data tracked each other illustrating that the daily canister samples 
captured a wide range of air mass types and compositions including background air masses and significant winter pollution events with enhanced NMHC mixing ratios.

The percent difference between the emission rates calculated from the TF GC nighttime data (Eq. 1) and the daily canister emission ratios (Eq. 2) ranged between $\pm 5-80 \%$ (Table 3 ). The emission rate of propane ( $\sim 2$ to $4 \times 10^{10}$ molecules $\mathrm{cm}^{-2} \mathrm{~s}^{-1}$ ) was $1-2$ orders of magnitude larger than the other NMHCs (range 0.2$7 \times 10^{9}$ molecules $\mathrm{cm}^{-2} \mathrm{~s}^{-1}$ ) (Table 3). The high propane emission rate is another indication of the persistent impact of leakage from LPG tanks or refilling stations throughout the region (Sect. 4.2). Additionally, assuming the TF results are representative of the state and region, the NMHC emission rates extrapolated to the state of New Hampshire and New England are $\sim 2-61 \mathrm{Mg}$ /day and $\sim 12-430 \mathrm{Mg}$ /day, respectively (Table 3). The emission rates of propane, i-butane, and n-butane from New Hampshire were 20-90\% lower than observed from LPG leakage in Mexico City, Mexico (Elliott et al., 1997) and in Santiago, Chile (Chen et al., 2001). However, taking into consideration the larger land area for New Hampshire and New England, our results suggest that potential emissions of $\mathrm{C}_{3}-\mathrm{C}_{4}$ alkanes from the northeast US are comparable to emission rates that have been observed in densely populated urban areas (see also White et al., 2008). Furthermore, these high levels of precursor compounds in air masses transported to and across the North Atlantic may contribute to $\mathrm{O}_{3}$ and aerosol production, thus influencing the air quality of downwind regions.

Emission rates determined using the daily canister emission ratios from winters 2004, 2005, 2007, or 2008 were within $\sim 10-50 \%$ of the winter 2006 values. In addition, the winter 2006 emission rates of propane, i-butane, $n$-butane, ipentane, and propene agreed (within factors of $\sim 0.7-6$ ) with estimates made using nighttime measurements from the automated TF GC during summers 2003 and 2004 (White et al., 2008). The consistency between the estimates for different winters and for winter and summer suggests that emission rates do not appear to be varying detectably with season or year. We consider the fact that the winter $2006 \mathrm{TF}$ GC and daily canister emission rates and the summer 2003 and 2004 emission rates from White et al. (2008) agree within an order of magnitude (with the exception of $m+p$-xylene) to be good agreement. Furthermore, despite the different areas (i.e., source footprints) potentially represented by the TF GC and daily canister emission rates, both approaches yield similar results. Possible explanations for this similarity include: (1) the two estimates are not completely independent because the daily canister emissions are calculated using the TF GC ethyne emission rate; (2) local NMHC emission rates are similar to rates throughout New England; (3) the midday daily canister emission rates retain a signature from local nighttime emissions following the breakup of the NBL and subsequent mixing with remnant air from the previous day's mixed layer in the morning. Overall, this analysis provides
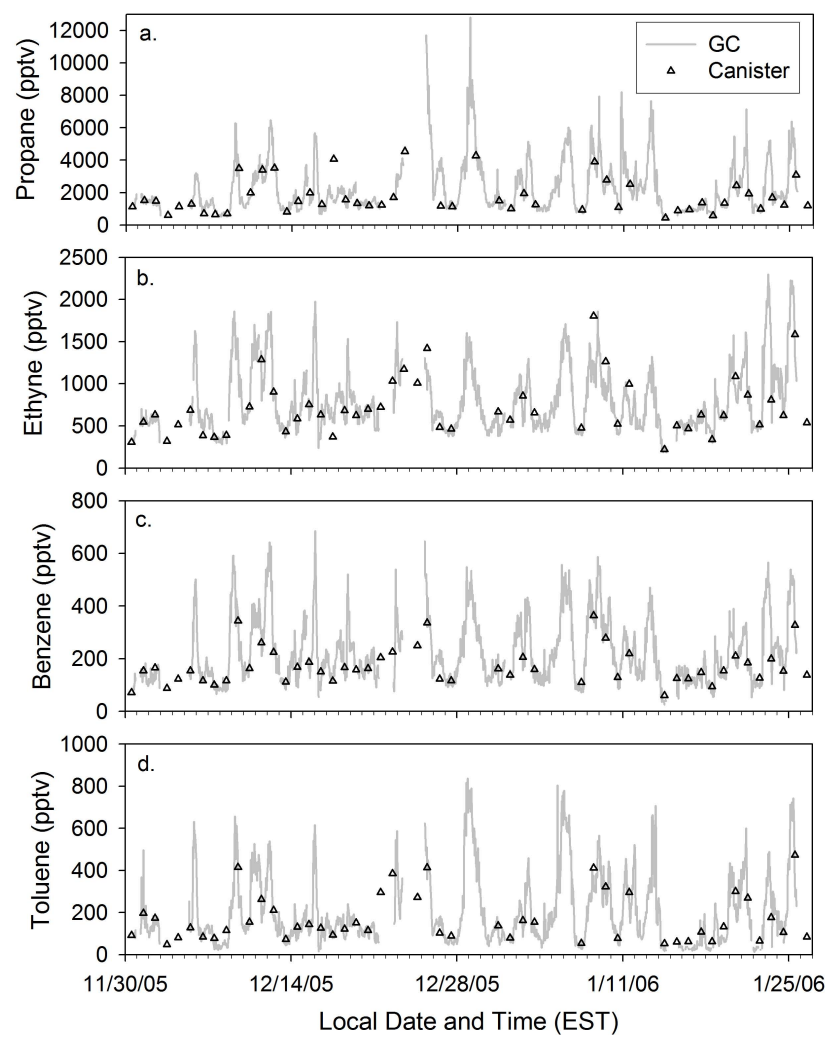

Fig. 11. Comparison between (a) propane, (b) ethyne, (c) benzene, and (d) toluene data from the automated TF GC system during December 2005-January 2006 and the daily canister samples collected during the same time period. Note: the canister samples with mixing ratios $>95$ th percentile for each month have been removed.

promising results that the daytime canister samples provide representative information on regional emission rates.

\subsection{Comparison with the 2002 and 2005 EPA National Emissions Inventory}

The emission rates of benzene, toluene, ethylbenzene, xylenes, and ethyne in the two most recent versions (2002 and 2005) of the EPA National Emissions Inventory (NEI) (www.epa.gov/ttn/chief/net) were compared with each other and with the emission rates estimated at TF (Sect. 5.1). These five NMHCs were chosen because the NEI provides speciated emission rates for some toxic compounds (including aromatics) and because ethyne or VOC/ethyne ratios are commonly used as tracers of specific sources. The emission rates of benzene, toluene, ethylbenzene, and xylenes for $\mathrm{NH}$ from the major source categories (onroad, nonroad, nonpoint, point) were obtained directly from the NEI. Emission rates of ethyne were estimated using the total VOC emissions from its major sources (gasoline and diesel exhaust, recreational equipment, lawn and garden equipment, and stationary source fuel combustion) and the EPA recommended 
Table 3. Emission rates (molecules $\mathrm{cm}^{-2} \mathrm{~s}^{-1}$ ) of $\mathrm{C}_{3}-\mathrm{C}_{8}$ NMHCs calculated using nighttime measurements made by the automated TF GC when a stable inversion layer developed during winter 2006. The error bars were calculated by propagating the standard error of the linear regression between the change in NMHC concentration per unit time (00:00-05:00 EST) and the assumed variation in nocturnal boundary layer height $(125 \mathrm{~m} \pm 75 \mathrm{~m})$. The winter 2006 daily canister emission ratio ( \pm standard error (SE)) was calculated from the slope of the correlation between a NMHC and ethyne. The winter 2006 daily canister emission rate (molecules $\mathrm{cm}^{-2} \mathrm{~s}^{-1}$ ) was calculated by multiplying the daily canister emission ratios by the TF GC ethyne emission rate. The error bars were calculated by propagating the error associated with the winter 2006 TF GC ethyne emission rate and the standard error of the NMHC/ethyne emission ratio. New Hampshire (land area $=2.3 \times 10^{10} \mathrm{~m}^{2}$ ) and New England (land area $=1.6 \times 10^{11} \mathrm{~m}^{2}$ ) emissions $(\mathrm{Mg} /$ day) were extrapolated from the winter $2006 \mathrm{TF}$ GC emission rates.

\begin{tabular}{|c|c|c|c|c|c|c|c|}
\hline & \multicolumn{2}{|c|}{$\begin{array}{l}\text { Winter } 2006 \text { TF GC } \\
\text { Emission Rate }\end{array}$} & \multicolumn{2}{|c|}{$\begin{array}{c}\text { Winter } 2006 \text { Daily } \\
\text { Canister Emission Ratio }\end{array}$} & \multirow{2}{*}{$\begin{array}{c}\begin{array}{c}\text { Winter } 2006 \text { Daily } \\
\text { Canister Emission Rate }\end{array} \\
\times 10^{9} \\
\text { (molec. } \mathrm{cm}^{-2} \mathrm{~s}^{-1} \text { ) }\end{array}$} & \multirow{2}{*}{$\begin{array}{c}\text { New } \\
\text { Hampshire }\end{array}$} & \multirow{2}{*}{$\begin{array}{c}\text { New } \\
\text { England }\end{array}$} \\
\hline & $\begin{array}{c}\times 10^{9} \\
\left(\text { molec. } \mathrm{cm}^{-2} \mathrm{~s}^{-1}\right)\end{array}$ & $r^{2}$ & $\left(\frac{\text { NMHC }}{\text { Ethyne }}\right) \pm S E$ & $r^{2}$ & & & \\
\hline Ethyne & $7.4 \pm 4.9$ & 0.78 & & & & $6.4 \pm 4.2$ & $45 \pm 30$ \\
\hline Propane & $42 \pm 25$ & 0.96 & $2.33 \pm 0.25$ & 0.57 & $17 \pm 12$ & $61 \pm 37$ & $427 \pm 260$ \\
\hline Propene & $3.2 \pm 2.0$ & 0.86 & $0.25 \pm 0.02$ & 0.75 & $1.8 \pm 1.2$ & $4.5 \pm 2.9$ & $32 \pm 20$ \\
\hline i-Butane & $3.2 \pm 2.0$ & 0.89 & $0.44 \pm 0.04$ & 0.60 & $3.3 \pm 2.0$ & $6.1 \pm 3.8$ & $43 \pm 27$ \\
\hline n-Butane & $3.6 \pm 2.3$ & 0.83 & $0.85 \pm 0.13$ & 0.40 & $6.3 \pm 4.1$ & $6.9 \pm 4.4$ & $49 \pm 31$ \\
\hline i-Pentane & $2.4 \pm 1.5$ & 0.94 & $0.43 \pm 0.04$ & 0.68 & $3.2 \pm 2.1$ & $5.8 \pm 3.6$ & $41 \pm 25$ \\
\hline n-Pentane & $1.4 \pm 0.8$ & 0.96 & $0.22 \pm 0.03$ & 0.46 & $1.6 \pm 1.0$ & $3.3 \pm 2.0$ & $23 \pm 14$ \\
\hline n-Hexane & $0.6 \pm 0.4$ & 0.87 & $0.09 \pm 0.01$ & 0.61 & $0.7 \pm 0.4$ & $1.7 \pm 1.1$ & $12 \pm 8$ \\
\hline Benzene & $1.6 \pm 1.1$ & 0.81 & $0.19 \pm 0.01$ & 0.94 & $1.4 \pm 0.9$ & $4.3 \pm 2.8$ & $30 \pm 19$ \\
\hline Toluene & $2.7 \pm 1.7$ & 0.82 & $0.30 \pm 0.02$ & 0.79 & $2.3 \pm 1.5$ & $8.2 \pm 5.3$ & $58 \pm 37$ \\
\hline Ethylbenzene & $0.5 \pm 0.3$ & 0.86 & $0.04 \pm 0.003$ & 0.69 & $0.3 \pm 0.2$ & $1.8 \pm 1.1$ & $13 \pm 8$ \\
\hline $\mathrm{m}+\mathrm{p}-\mathrm{Xylene}$ & $1.3 \pm 0.8$ & 0.80 & $0.04 \pm 0.004$ & 0.61 & $0.3 \pm 0.2$ & $4.4 \pm 2.9$ & $31 \pm 20$ \\
\hline o-Xylene & $0.5 \pm 0.3$ & 0.88 & $0.03 \pm 0.002$ & 0.65 & $0.2 \pm 0.1$ & $1.8 \pm 1.1$ & $13 \pm 8$ \\
\hline
\end{tabular}

composite profiles for those sources. The speciation profiles were obtained from the SPECIATE 4.2 database (http: //projects.pechan.com/ttn/speciate4.2.1).

The emission rates of benzene, toluene, ethylbenzene, xylenes, and ethyne in both the 2002 and 2005 NEI agreed within the error limits and were the same order of magnitude as the TF emission rates (Table 4). The emission rates of benzene, ethylbenzene, and xylenes were fairly similar (within $\pm 15 \%)$ in the two versions of the NEI. The relative distribution of emissions in the NEI and at TF was the same in 2002 with toluene $>$ xylenes $\sim$ ethyne $>$ benzene $>$ ethylbenzene. Toluene and ethylbenzene had the highest and lowest emission rates, respectively, in the $2005 \mathrm{NEI}$ as well. Overall, it appears that the 2002 NEI emission estimates were in better agreement with the TF emission rates than the 2005 NEI.

A notable difference between the two versions of the NEI is the higher toluene emissions from nonroad sources (specifically recreational, lawn, and garden equipment) in 2005 than in 2002 (Table 4). While still within the error limits, the largest difference between the central TF emission rate and the NEI was for toluene (out of the five compounds shown in Table 4). The 2002 and 2005 total NEI toluene emissions were $30 \%$ and $50 \%$, respectively, higher than the TF estimates. Toluene has many potential sources in this region (e.g., vehicular exhaust, fuel evaporation, solvent utilization, biogenic, White et al., 2009) which is a likely fac- tor contributing to the disagreement between the inventory and our estimates. Previous studies focused on the eastern US have reported that toluene emissions were overestimated in earlier versions of the NEI. For example, Choi et al. (2006) found that toluene emissions were overestimated in a modified version of the 1996 NEI compared to PAMS measurements made in Mid-Atlantic states. In contrast to this work in which the higher toluene in 2005 was associated with larger nonroad emissions, the overestimate reported by Choi et al. (2006) was related to solvent utilization. Furthermore, WRF-CHEM model predictions based on the 1999 NEI of the vertical profile of toluene over the northeast US during the NEAQS-ITCT 2004 campaign were approximately a factor of 3 larger than observations (Warneke et al., 2007). Toluene is an important precursor of $\mathrm{O}_{3}$ and SOA which highlights the critical need for updated source profiles, improved inventory emission estimates, and additional observational constraints on toluene emissions.

The total $2002 \mathrm{NEI}$ and TF ethyne emission rates agreed remarkably well ( $\sim 2300 \mathrm{Mg} /$ year) (Table 4$)$. However, the total 2005 NEI ethyne emission rate was $\sim 40 \%$ lower than the central TF value, but was still within the error limits of the TF emission rate. Ethyne emissions in the nonpoint source category reflect residential stationary source fuel combustion with a minor contribution from open burning (yard and household waste). Residential wood and fireplace 
Table 4. Emission rates (Mg/year) of benzene, toluene, ethylbenzene, xylenes $(m+p+o)$, and ethyne and the toluene/benzene and benzene/ethyne ratios from the 2002 and 2005 EPA National Emissions Inventory (NEI) for New Hampshire. The TF column is the emission rate (Mg/year) estimated using the winter $2006 \mathrm{TF}$ GC nighttime measurements from Table 3. The toluene/benzene and benzene/ethyne ratios were calculated by converting the emission rates for TF and for the respective source category listed in this table to molar concentrations. The $\mathrm{TF}$ toluene/benzene and benzene/ethyne ratio errors were propagated from the error in the $\mathrm{TF}$ emission rates.

\begin{tabular}{|c|c|c|c|c|c|c|c|}
\hline & & Onroad Exhaust & Onroad Evaporation & Nonroad & Nonpoint & Point & Total \\
\hline & $\mathrm{TF}$ & \multicolumn{6}{|c|}{2002 NEI } \\
\hline Benzene & $1555 \pm 1000$ & 540 & 25 & 730 & 520 & 10 & 1830 \\
\hline Toluene & $3000 \pm 1900$ & 1400 & 160 & 1660 & 480 & 100 & 3800 \\
\hline Ethylbenzene & $660 \pm 400$ & 200 & 30 & 365 & 25 & 30 & 650 \\
\hline Xylenes & $2260 \pm 830$ & 790 & 100 & 1120 & 260 & 120 & 2390 \\
\hline Ethyne & $2350 \pm 1540$ & 390 & & 540 & 1370 & 2 & 2300 \\
\hline Toluene/Benzene & $1.6 \pm 1.4$ & 2.2 & 5.4 & 1.9 & 0.78 & 8.4 & 1.8 \\
\hline \multirow[t]{2}{*}{ Benzene/Ethyne } & $0.22 \pm 0.2$ & 0.46 & & 0.45 & 0.13 & 1.7 & 0.26 \\
\hline & $\mathrm{TF}$ & \multicolumn{6}{|c|}{2005 NEI } \\
\hline Benzene & $1555 \pm 1000$ & 650 & 30 & 400 & 480 & 10 & 1570 \\
\hline Toluene & $3000 \pm 1900$ & 1450 & 160 & 2340 & 520 & 90 & 4560 \\
\hline Ethylbenzene & $660 \pm 400$ & 210 & 30 & 275 & 30 & 5 & 550 \\
\hline Xylenes & $2260 \pm 830$ & 820 & 100 & 1280 & 290 & 40 & 2530 \\
\hline Ethyne & $2350 \pm 1540$ & 405 & & 640 & 430 & 5 & 1480 \\
\hline Toluene/Benzene & $1.6 \pm 1.4$ & 1.9 & 4.5 & 5.0 & 0.92 & 7.6 & 2.5 \\
\hline Benzene/Ethyne & $0.22 \pm 0.2$ & 0.53 & & 0.21 & 0.37 & 0.67 & 0.35 \\
\hline
\end{tabular}

combustion was the largest nonpoint source of VOC emissions in northern New England in both versions of the NEI. According to the EPA, the emission factor used to calculate emissions for the woodstove and fireplace source category was reduced for the $2005 \mathrm{NEI}$ (www.epa.gov/ttn/chief/ net/2005inventory). Consequently, the VOC emission rate from the woodstove and fireplace source category was $\sim 70 \%$ lower in the 2005 NEI than in the 2002 NEI. This resulted in the lower ethyne emissions in 2005 and the larger discrepancy with the TF emission rates. This illustrates the necessity of additional studies to accurately quantify the VOC emissions from residential combustion in the northeast US (e.g., Jordan et al., 2009).

The toluene/benzene and benzene/ethyne ratios based on the NEI emissions for New Hampshire were also examined and compared to the ambient ratios (Sects. 4.2 and 4.3) (Table 4). Both the 2002 and 2005 NEI toluene/benzene and benzene/ethyne ratios agreed within the error limits of the $\mathrm{TF}$ ratio values. The total benzene/ethyne ratios in the $2002(0.26)$ and $2005(0.35)$ NEIs were lower than the ratios given in Parrish (2006) for the 1996 and 1999 NEIs (0.9 and 0.7 , respectively). The benzene/ethyne ratio in the onroad exhaust source category $(\sim 0.5)$ was higher than ambient ratios $(\sim 0.2)$. Our results are consistent with Parrish (2006) who reported that there was a downward trend in NEI benzene/ethyne ratio values but that there are still problems with the apportioning of benzene and ethyne emissions in the onroad source category. Overall, the range of NEI toluene/benzene and benzene/ethyne ratio values in the different source categories are within the range of the ambient values observed at TF (Table 4, Figs. 9, 10). The general agreement between our results and the inventory may be fortuitous or it may indicate that VOC emissions are more accurately represented in the 2002 and 2005 NEIs than in earlier versions. Furthermore, these results suggest that the ethyne emission rate from the NEI may be useful for estimating emission rates of other VOCs by using their emission ratios relative to ethyne from the daily canister samples. This may be a valuable tool for modeling or predicting ambient VOC concentrations.

\section{Summary}

This work characterized the mixing ratios, seasonal to interannual variability, and sources of $\mathrm{C}_{2}-\mathrm{C}_{8} \mathrm{NMHCs}, \mathrm{C}_{2} \mathrm{HCl}_{3}$, and $\mathrm{C}_{2} \mathrm{Cl}_{4}$ from samples collected during January 2004February 2008 at Thompson Farm in Durham, NH. The midday canister samples provided a comprehensive and representative picture of the day-to-day and interannual VOC trends and captured a wide range of mixing ratios and various sources (fossil fuel combustion, gasoline, LPG, fuel or solvent evaporation, industry, biogenic). Estimates of NMHC emission rates using the daily canister sample and 
automated in situ TF GC measurements ranged from $10^{9}$ $10^{10}$ molecules $\mathrm{cm}^{-2} \mathrm{~s}^{-1}$. Additionally, benzene, toluene, ethylbenzene, xylene, and ethyne emission rates from the 2002 and 2005 EPA National Emissions Inventory were within $\pm 50 \%$ of the TF emission rates. The alkanes, ethyne, benzene, toluene, and halocarbons exhibited consistent and reproducible seasonal trends each year, whereas the alkenes and $\mathrm{C}_{8}$ aromatics illustrated greater interannual variability reflecting their shorter lifetimes and/or varying sources or emission rates. Furthermore, this multi-year data set illustrated that the mixing ratios of reactive $\mathrm{NMHCs}_{\text {(specifi- }}$ cally $\mathrm{C}_{5}-\mathrm{C}_{6}$ alkanes, propene, toluene), and $\mathrm{C}_{2} \mathrm{HCl}_{3}$ were enhanced in the summer relative to their springtime minimums indicating a persistent influence from evaporative emissions each year. Previous fuel emission studies have observed increased evaporative emissions from gasoline containing ethanol (e.g., Durbin et al., 2007; Graham et al., 2008). The results from this study will be valuable for evaluating and documenting the impact of new federal regulations enacted in 2005-2007 for motor vehicle emissions (http: //www.epa.gov/otaq/gasoline) (i.e., MTBE ban and switch to E10) and dry cleaning solvents on the ambient levels of VOCs in this region.

Acknowledgements. We would like to thank Karl Haase, Jesse Ambrose, Elizabeth Frinak, and Leanna Conway for canister analysis, data reduction, and instrument maintenance, Lissa Ducharme for chromatogram integration, and AIRMAP staff for maintenance of the monitoring sites and management of the database. We would also like to express our thanks to the two anonymous reviewers for their helpful and insightful comments and suggestions. Financial support for this work was provided to AIRMAP through the Office of Oceanic and Atmospheric Research at the National Oceanic and Atmospheric Administration.

Edited by: J. G. Murphy

\section{References}

Atkinson, R., Baulch, D. L., Cox, R. A., Crowley, J. N., Hampson, R. F., Hynes, R. G., Jenkin, M. E., Rossi, M. J., Troe, J., and IUPAC Subcommittee: Evaluated kinetic and photochemical data for atmospheric chemistry: Volume II gas phase reactions of organic species, Atmos. Chem. Phys., 6, 3625-4055, doi:10.5194/acp-6-3625-2006, 2006.

Baker, A. K., Beyersdorf, A. J., Doezema, L. A., Katzenstein, A., Meinardi, S., Simpson, I. J., Blake, D. R., and Rowland, F. S.: Measurements of nonmethane hydrocarbons in 28 United States cites, Atmos. Environ., 42, 170-182, 2008.

Barletta, B., Meinardi, S., Simpson, I. J., Khwaja, H. A., Blake, D. R., and Rowland, F. S.: Mixing ratios of volatile organic compounds (VOCs) in the atmosphere of Karachi, Pakistan, Atmos. Environ., 36, 3429-3443, 2002.

Barletta, B., Meinardi, S., Simpson, I. J., Zou, S. C., Rowland, F. S., and Blake, D. R.: Ambient mixing ratios of nonmethane hydrocarbons (NMHCs) in two major urban centers of the Pearl River Delta (PRD) region: Guangzhou and Dongguan, Atmos.
Environ., 42, 4393-4408, doi:10.1016/j.atmosenv.2008.01.028, 2008.

Barnes, D. H., Wofsy, S. C., Fehlau, B. P., Gottlieb, E. W., Elkins, J. W., Dutton, G. S., and Montzka, S. A.: Urban/industrial pollution for the New York City - Washington, DC, corridor, 1996-1998: 1. Providing independent verification of CO and PCE emissions inventories, J. Geophys. Res., 108, 4185, doi:10.1029/2001jd001116, 2003.

Blake, D. R. and Rowland, F. S.: Urban leakage of liquefied petroleum gas and its impact on Mexico City air quality, Science, 269, 953-956, 1995.

Boissard, C., Bonsang, B., Kanakidou, M., and Lambert, G.: TROPOZ II: Global distributions and budgets of methane and light hydrocarbons, J. Atmos. Chem., 25, 115-148, 1996.

Bottenheim, J. W., and Shepherd, M. F.: $\mathrm{C}_{2}-\mathrm{C}_{6}$ hydrocarbon measurements at 4 rural locations across Canada, Atmos. Environ., 29, 647-664, 1995.

Bowman, F. M. and Seinfeld, J. H.: Atmospheric chemistry of alternate fuels and reformulated gasoline components, Prog. Energ. Combust., 21, 387-417, 1995.

Carter, W. P. L.: Development of ozone reactivity scales for volatile organic compounds, J. Air Waste Manage. Assoc., 44, 881-899, 1994.

Carter, W. P. L.: Development of the SAPRC-07 chemical mechanism and updated ozone reactivity scales, Final report to the California Air Resources Board, Contract No. 03-318 (available at: http://www.cert.ucr.edu/ carter/SAPRC/index.htm), 2008.

Chen, M., Talbot, R., Mao, H. T., Sive, B., Chen, J. J., and Griffin, R. J.: Air mass classification in coastal New England and its relationship to meteorological conditions, J. Geophys. Res., 112, D10S05, doi:10.1029/2006jd007687, 2007.

Chen, T. Y., Simpson, I. J., Blake, D. R., and Rowland, F. S.: Impact of the leakage of liquefied petroleum gas (LPG) on Santiago air quality, Geophys. Res. Lett., 28, 2193-2196, 2001.

Choi, Y.-J. and Ehrman, S. H.: Investigation of sources of volatile organic carbon in the Baltimore area using highly time-resolved measurements, Atmos. Environ., 38, 775-791, doi:10.1016/j.atmosenv.2003.10.004, 2004.

Choi, Y.-J., Calabrese, R. V., Ehrman, S. H., Dickerson, R. R., and Stehr, J. W.: A combined approach for the evaluation of a volatile organic compound emissions inventory, J. Air Waste Manage. Assoc., 56, 169-178, 2006.

Conner, T. L., Lonneman, W. A., and Seila, R. L.: Transportation related volatile hydrocarbon source profiles measured in Atlanta, J. Air Waste Manage. Assoc., 45, 383-394, 1995.

de Gouw, J. A., Middlebrook, A. M., Warneke, C., Goldan, P. D., Kuster, W. C., Roberts, J. M., Fehsenfeld, F. C., Worsnop, D. R., Canagaratna, M. R., Pszenny, A. A. P., Keene, W. C., Marchewka, M., Bertman, S. B., and Bates, T. S.: Budget of organic carbon in a polluted atmosphere: Results from the New England Air Quality Study in 2002, J. Geophys. Res., 110, D16305, doi:10.1029/2004jd005623, 2005.

Dimmer, C. H., McCulloch, A., Simmonds, P. G., Nickless, G., Bassford, M. R., and Smythe-Wright, D.: Tropospheric concentrations of the chlorinated solvents, tetrachloroethene and trichloroethene, measured in the remote northern hemisphere, Atmos. Environ., 35, 1171-1182, 2001.

Durbin, T. D., Miller, J. W., Younglove, T., Huai, T., and Cocker, $\mathrm{K}$. .: Effects of fuel ethanol content and volatility on regulated and 
unregulated exhaust emissions for the latest technology gasoline vehicles, Environ. Sci. Technol., 41, 4059-4064, 2007.

Elliott, S., Blake, D. R., Rowland, F. S., Lu, R., Brown, M. J., Williams, M. D., Russell, A. G., Bossert, J. E., Streit, G. E., Santoyo, M. R., Guzman, F., Porch, W. M., McNair, L. A., Keyantash, J., Kao, C. Y. J., Turco, R. P., and Eichinger, W. E.: Ventilation of liquefied petroleum gas components from the Valley of Mexico, J. Geophys. Res., 102, 21197-21207, 1997.

Fehsenfeld, F., Calvert, J., Fall, R., Goldan, P., Guenther, A. B., Hewitt, C. N., Lamb, B., Liu, S., Trainer, M., Westberg, H., and Zimmerman, P.: Emissions of volatile organic compounds from vegetation and the implications for atmospheric chemistry, Global Biogeochem. Cy., 6, 389-430, 1992.

Fischer, E. V., Talbot, R. W., Dibb, J. E., Moody, J. L., and Murray, G. L.: Summertime ozone at Mount Washington: Meteorological controls at the highest peak in the northeast, J. Geophys. Res., 109, D24303, doi:10.1029/2004jd004841, 2004.

Flocke, F., Volzthomas, A., and Kley, D.: Measurements of alkyl nitrates in rural and polluted air masses, Atmos. Environ. A-Gen, 25, 1951-1960, 1991.

Fortin, T. J., Howard, B. J., Parrish, D. D., Goldan, P. D., Kuster, W. C., Atlas, E. L., and Harley, R. A.: Temporal changes in US benzene emissions inferred from atmospheric measurements, Environ. Sci. Technol., 39, 1403-1408, 2005.

Fujita, E. M., Watson, J. G., Chow, J. C., and Magliano, K. L.: Receptor model and emissions inventory source apportionments of nonmethane organic gases in California's San Joaquin valley and San Francisco bay area, Atmos. Environ., 29, 3019-3035, 1995.

Fujita, E. M.: Hydrocarbon source apportionment for the 1996 Paso del Norte Ozone Study, Sci. Total Environ., 276, 171-184, 2001.

Gautrois, M., Brauers, T., Koppmann, R., Rohrer, F., Stein, O., and Rudolph, J.: Seasonal variability and trends of volatile organic compounds in the lower polar troposphere, J. Geophys. Res., 108, 4393, doi:10.1029/2002jd002765, 2003.

Gilman, J. G., Kuster, W. C., Goldan, P. D., Herndon, S. C., Zahniser, M. S., Tucker, S. C., Brewer, W. A., Lerner, B. M., Williams, E. J., Harley, R. H, Fehsenfeld, F. C., Warneke, C., and de Gouw, J. A.: Measurements of volatile organic compounds during the 2006 TexAQS/GoMACCS campaign: Industrial influences, regional characteristics, and diurnal dependencies of the OH reactivity, J. Geophys. Res., 114, D00F06, doi:10.1029/2008JD011525, 2009.

Goldan, P. D., Kuster, W. C., Fehsenfeld, F. C., and Montzka, S. A.: Hydrocarbon measurements in the southeastern United States: The Rural Oxidants in the Southern Environment (ROSE) program 1990, J. Geophys. Res., 100, 25945-25963, 1995.

Goldan, P. D., Parrish, D. D., Kuster, W. C., Trainer, M., McKeen, S. A., Holloway, J., Jobson, B. T., Sueper, D. T., and Fehsenfeld, F. C.: Airborne measurements of isoprene, CO, and anthropogenic hydrocarbons and their implications, J. Geophys. Res., 105, 9091-9105, 2000.

Goldan, P. D., Kuster, W. C., Williams, E., Murphy, P. C., Fehsenfeld, F. C., and Meagher, J.: Nonmethane hydrocarbon and oxy hydrocarbon measurements during the 2002 New England Air Quality Study, J. Geophys. Res., 109, D21309, doi:1029/2003JD004455, 2004.

Goldstein, A. H., Wofsy, S. C., and Spivakovsky, C. M.: Seasonal variations of nonmethane hydrocarbons in rural New England:
Constraints on $\mathrm{OH}$ concentrations in northern midlatitudes, J. Geophys. Res., 100, 26273-26274, 1995.

Gong, Q., and Demerjian, K. L.: Measurement and analysis of $\mathrm{C}_{2}-$ $\mathrm{C}_{10}$ hydrocarbons at Whiteface Mountain, New York, J. Geophys. Res., 102, 28059-28069, 1997.

Graham, L. A., Belisle, S. L., and Baas, C.-L.: Emissions from light duty gasoline vehicles operating on low blend ethanol gasoline and E85, Atmos. Environ., 42, 4498-4516, 2008.

Griffin, R. J., Beckman, P. J., Talbot, R. W., Sive, B. C., and Varner, R. K.: Deviations from ozone photostationary state during the International Consortium for Atmospheric Research on Transport and Transformation 2004 campaign: Use of measurements and photochemical modeling to assess potential causes, J. Geophys. Res., 112, D10S07, doi:10.1029/2006JD007604, 2007.

Guenther, A., Hewitt, C. N., Erickson, D., Fall, R., Geron, C., Graedel, T., Harley, P., Klinger, L., Lerdau, M., McKay, W. A., Pierce, T., Scholes, B., Steinbrecher, R., Tallamraju, R., Taylor, J., and Zimmerman, P.: A global model of natural volatile organic compound emissions, J. Geophys. Res., 100(D5), 88738892, 1995.

Gupta, M. L., Cicerone, R. J., Blake, D. R., Rowland, F. S., and Isaksen, I. S. A.: Global atmospheric distributions and source strengths of light hydrocarbons and tetrachloroethene, J. Geophys. Res., 103, 28219-28235, 1998.

Gusten, H., Heinrich, G., and Sprung, D.: Nocturnal depletion of ozone in the Upper Rhine Valley, Atmos. Environ., 32, 1195$1202,1998$.

Hagerman, L. M., Aneja, V. P., and Lonneman, W. A.: Characterization of non-methane hydrocarbons in the rural southeast United States, Atmos. Environ., 31, 4017-4038, 1997.

Harley, R. A., Hannigan, M. P., and Cass, G. R.: Respeciation of organic gas emissions and the detection of excess unburned gasoline in the atmosphere Environ. Sci. Technol., 26, 2395-2408, 1992.

Harley, R. A., McKeen, S. A., Pearson, J., Rodgers, M. O., and Lonneman, W. A.: Analysis of motor vehicle emissions during the Nashville/Middle Tennessee Ozone Study, J. Geophys. Res., 106, 3559-3567, 2001.

Harley, R. A., Hooper, D. S., Kean, A. J., Kirchstetter, T. W., Hesson, J. M., Balberan, N. T., Stevenson, E. D., and Kendall, G. R.: Effects of reformulated gasoline and motor vehicle fleet turnover on emissions and ambient concentrations of benzene, Environ. Sci. Technol., 40, 5084-5088, doi:10.1021/es0604820, 2006.

Hastie, D. R., Shepson, P. B., Sharma, S., and Schiff, H. I.: The influence of the nocturnal boundary layer on secondary trace species in the atmosphere at Dorset, Ontario, Atmos. Environ. A-Gen., 27, 533-541, 1993.

Hudman, R. C., Murray, L. T., Jacob, D. J., Millet, D. B., Turquety, S., Wu, S., Blake, D. R., Goldstein, A. H., Holloway, J., and Sachse, G. W.: Biogenic versus anthropogenic sources of CO in the United States, Geophys. Res. Lett., 35, L04801, doi:10.1029/2007GL032393, 2008.

Hurst, D. F., Bakwin, P. S., and Elkins, J. W.: Recent trends in the variability of halogenated trace gases over the United States, J. Geophys. Res., 103, 25299-25306, 1998.

Jobson, B. T., Wu, Z., Niki, H., and Barrie, L. A.: Seasonal trends of isoprene, $\mathrm{C}_{2}-\mathrm{C}_{5}$ alkanes, and acetylene at a remote boreal site in Canada J. Geophys. Res., 99, 1589-1599, 1994.

Jobson, B. T., Parrish, D. D., Goldan, P., Kuster, W., Fehsenfeld, 
F. C., Blake, D. R., Blake, N. J., and Niki, H.: Spatial and temporal variability of nonmethane hydrocarbon mixing ratios and their relation to photochemical lifetime, J. Geophys. Res., 103, 13557-13567, 1998.

Jobson, B. T., McKeen, S. A., Parrish, D. D., Fehsenfeld, F. C., Blake, D. R., Goldstein, A. H., Schauffler, S. M., and Elkins, J. C.: Trace gas mixing ratio variability versus lifetime in the troposphere and stratosphere: Observations, J. Geophys. Res., 104, 16091-16113, 1999.

Jobson, B. T., Berkowitz, C. M., Kuster, W. C., Goldan, P. D., Williams, E. J., Fehsenfeld, F. C., Apel, E. C., Karl, T., Lonneman, W. A., and Riemer, D.: Hydrocarbon source signatures in Houston, Texas: Influence of the petrochemical industry, J. Geophys. Res., 109, D24305, doi:10.1029/2004jd004887, 2004.

Jordan, C., Fitz, E., Hagan, T., Sive, B., Frinak, E., Haase, K., Cottrell, L., Buckley, S., and Talbot, R.: Long-term study of VOCs measured with PTR-MS at a rural site in New Hampshire with urban influences, Atmos. Chem. Phys., 9, 4677-4697, doi:10.5194/acp-9-4677-2009, 2009.

Kang, D. W., Aneja, V. P., Zika, R. G., Farmer, C., and Ray, J. D.: Nonmethane hydrocarbons in the rural southeast United States national parks, J. Geophys. Res., 106, 3133-3155, 2001.

Kirchstetter, T. W., Singer, B. C., Harley, R. A., Kendall, G. B., and Chan, W.: Impact of oxygenated gasoline use on California light-duty vehicle emissions, Environ. Sci. Technol., 30, 661670,1996

Kleiman, G. and Prinn, R. G.: Measurement and deduction of emissions of trichloroethene, tetrachloroethene, and trichloromethane (chloroform) in the northeastern United States and southeastern Canada, J. Geophys. Res., 105, 28875-28893, 2000.

Kleinman, L. I., Daum, P. H., Lee, Y. N., Nunnermacker, L. J., Springston, S. R., Weinstein-Lloyd, J., Hyde, P., Doskey, P., Rudolph, J., Fast, J., and Berkowitz, C.: Photochemical age determinations in the Phoenix metropolitan area, J. Geophys. Res., 108, 4096, doi:10.1029/2002jd002621, 2003.

Kleinman, L. I., Daum, P. H., Lee, Y. N., Nunnermacker, L. J., Springston, S. R., Weinstein-Lloyd, J., and Rudolph, J.: A comparative study of ozone production in five U.S. metropolitan areas, J. Geophys. Res., 110, D02301, doi:10.1029/2004jd005096, 2005

Klemp, D., Kley, D., Kramp, F., Buers, H. J., Pilwat, G., Flocke, F., Patz, H. W., and VolzThomas, A.: Long-term measurements of light hydrocarbons $\left(\mathrm{C}_{2}-\mathrm{C}_{5}\right)$ at Schauinsland (Black Forest), J. Atmos. Chem., 28, 135-171, 1997.

Kroll, J. H. and Seinfeld, J. H.: Chemistry of secondary organic aerosol: Formation and evolution of low-volatility organics in the atmosphere, Atmos. Environ., 42, 3593-3624, doi:10.1016/j.atmosenv.2008.01.003, 2008.

Lawrimore, J. H. and Aneja, V. P.: A chemical mass balance analysis of nonmethane hydrocarbon emissions in North Carolina, Chemosphere, 35, 2751-2765, 1997.

Lee, B. H., Munger, J. W., Wofsy, S. C., and Goldstein, A. H.: Anthropogenic emissions of nonmethane hydrocarbons in the northeastern United States: Measured seasonal variations from 1992-1996 and 1999-2001, J. Geophys. Res., 111, D20307, doi:10.1029/2005jd006172, 2006.

Lough, G. C., Schauer, J. J., Lonneman, W. A., and Allen, M. K.: Summer and winter nonmethane hydrocarbon emissions from on-road motor vehicles in the Midwestern United States, J. Air
Waste Manage. Assoc., 55, 629-646, 2005.

Mao, H. T. and Talbot, R.: $\mathrm{O}_{3}$ and $\mathrm{CO}$ in New England: Temporal variations and relationships, J. Geophys. Res., 109, D21304, doi:10.1029/2004jd004913, 2004a.

Mao, H. T. and Talbot, R.: Role of meteorological processes in two New England ozone episodes during summer 2001, J. Geophys. Res., 109, D20305, doi:10.1029/2004jd004850, 2004 b.

Mao, H., Talbot, R. W., Sigler, J. M., Sive, B. C., and Hegarty, J. D.: Seasonal and diurnal variations of $\mathrm{Hg}^{\circ}$ over New England, Atmos. Chem. Phys., 8, 1403-1421, doi:10.5194/acp-8-1403-2008, 2008.

McCarthy, M. C., Hafner, H. R., and Montzka, S. A.: Background concentrations of 18 air toxics for North America, J. Air Waste Manage. Assoc., 56, 3-11, 2006.

McCulloch, A. and Midgley, P. M.: The production and global distribution of emissions of trichloroethene, tetrachloroethene and dichloromethane over the period 1988-1992, Atmos. Environ., 30, 601-608, 1996.

McGaughey, G. R., Desai, N. R., Allen, D. T., Seila, R. L., Lonneman, W. A., Fraser, M. P., Harley, R. A., Pollack, A. K., Ivy, J. M., and Price, J. H.: Analysis of motor vehicle emissions in a Houston tunnel during the Texas Air Quality Study 2000, Atmos. Environ., 38, 3363-3372, doi:10.1016/j.atmosenv.2004.03.006, 2004.

McKeen, S. A., Liu, S. C., Hsie, E. Y., Lin, X., Bradshaw, J. D., Smyth, S., Gregory, G. L., and Blake, D. R.: Hydrocarbon ratios during PEM-WEST A: A model perspective, J. Geophys. Res. 101, 2087-2109, 1996.

McKendry, I. G. and Lundgren, J.: Tropospheric layering of ozone in regions of urbanized complex and/or coastal terrain: a review, Prog. Phys. Geogr., 24, 329-354, 2000.

McLaren, R., Singleton, D. L., Lai, J. Y. K., Khouw, B., Singer, E., Wu, Z., and Niki, H.: Analysis of motor vehicle sources and their contribution to ambient hydrocarbon distributions at urban sites in Toronto during the Southern Ontario Oxidants Study, Atmos. Environ., 30, 2219-2232, 1996.

Millet, D. B., Donahue, N. M., Pandis, S. N., Polidori, A., Stanier, C. O., Turpin, B. J., and Goldstein, A. H.: Atmospheric volatile organic compound measurements during the Pittsburgh Air Quality Study: Results, interpretation, and quantification of primary and secondary contributions, J. Geophys. Res., 110, D07S07, doi:10.1029/2004JD004601, 2005.

Millet, D. B., Goldstein, A. H., Holzinger, R., Williamns, B. J., Allan, J. D., Jimenez, J. L., Worsnop, D. R., Roberts, J. M., White, A. B., Hudman, R. C., Bertschi, I. T., and Stohl, A.: Chemical characteristics of North American surface layer outflow: Insights from Chebogue Point, Nova Scotia, J. Geophys. Res., 111, D23S53, doi:10.1029/2006JD007287, 2006.

Mohamed, M. F., Kang, D. W., and Aneja, V. P.: Volatile organic compounds in some urban locations in United States, Chemosphere, 47, 863-882, 2002.

Moody, J. L., Munger, J. W., Goldstein, A. H., Jacob, D. J., and Wofsy, S. C.: Harvard forest regional-scale air mass composition by Patterns in Atmospheric Transport History (PATH), J. Geophys. Res., 103, 13181-13194, 1998.

Monod, A., Sive, B. C., Avino, P., Chen, T., Blake, D. R., and Rowland, F. S.: Monoaromatic compounds in ambient air of various cities: a focus on correlations between the xylenes and ethylbenzene, Atmos. Environ., 35, 135-149, 2001. 
Mukerjee, S., Norris, G. A., Smith, L. A., Noble, C. A., Neas, L. M., Ozkaynak, A. H., and Gonzales, M.: Receptor model comparisons and wind direction analyses of volatile organic compounds and submicrometer particles in an arid, binational, urban air shed, Environ. Sci. Technol., 38, 2317-2327, 2004.

Mukund, R., Kelly, T. J., and Spicer, C. W.: Source attribution of ambient air toxic and other VOCs in Columbus, Ohio, Atmos. Environ., 30, 3457-3470, 1996.

Munger, J. W., Wofsy, S. C., Bakwin, P. S., Fan, S. M., Goulden, M. L., Daube, B. C., Goldstein, A. H., Moore, K. E., and Fitzjarrald, D. R.: Atmospheric deposition of reactive nitrogen oxides and ozone in a temperate deciduous forest and a subarctic woodland. 1. Measurements and mechanisms, J. Geophys. Res., 101, 12639-12657, 1996.

Ng, N. L., Kroll, J. H., Chan, A. W. H., Chhabra, P. S., Flagan, R. C., and Seinfeld, J. H.: Secondary organic aerosol formation from m-xylene, toluene, and benzene, Atmos. Chem. Phys., 7, 3909-3922, doi:10.5194/acp-7-3909-2007, 2007.

Odum, J. R., Jungkamp, T. P. W., Griffin, R. J., Forstner, H. J. L., Flagan, R. C., and Seinfeld, J. H.: Aromatics, reformulated gasoline, and atmospheric organic aerosol formation, Environ. Sci. Technol., 31, 1890-1897, 1997.

Parrish, D. D., Trainer, M., Young, V., Goldan, P. D., Kuster, W. C., Jobson, B. T., Fehsenfeld, F. C., Lonneman, W. A., Zika, R. D., Farmer, C. T., Riemer, D. D., and Rodgers, M. O.: Internal consistency tests for evaluation of measurements of anthropogenic hydrocarbons in the troposphere, J. Geophys. Res., 103, 2233922359, 1998.

Parrish, D. D.: Critical evaluation of US on-road vehicle emission inventories, Atmos. Environ., 40, 2288-2300, doi:10.1016/j.atmosenv.2005.11.033, 2006.

Parrish, D., Kuster, W. C., Shao, M., Yokouchi, Y., Kondo, Y., Goldan, P., de Gouw, J., Koike, M., and Shirai, T: Comparison of air pollutant emissions among mega-cities, Atmos. Environ., 43, 6435-6441, 2009.

Qin, Y., Walk, T., Gary, R., Yao, X., and Elles, S.: $\mathrm{C}_{2}-\mathrm{C}_{10}$ nonmethane hydrocarbons measured in Dallas, USA - Seasonal trends and diurnal characteristics, Atmos. Environ., 41, 60186032, doi:10.1016/j.atmosenv.2007.03.008, 2007.

Roberts, J. M., Fehsenfeld, F. C., Liu, S. C., Bollinger, M. J., Hahn, C., Albritton, D. L., and Sievers, R. E.: Measurements of aromatic hydrocarbon ratios and $\mathrm{NO}_{\mathrm{X}}$ concentrations in the rural troposphere: Observation of air-mass photochemical aging and $\mathrm{NO}_{\mathrm{x}}$ removal, Atmos. Environ., 18, 2421-2432, 1984.

Roberts, J. M., Bertman, S. B., Parrish, D. D., Fehsenfeld, F. C., Jobson, B. T., and Niki, H.: Measurement of alkyl nitrates at Chebogue Point, Nova Scotia during the 1993 North Atlantic Regional Experiment (NARE) intensive, J. Geophys. Res., 103, 13569-13580, 1998.

Rogak, S. N., Pott, U., Dann, T., and Wang, D.: Gaseous emissions from vehicles in a traffic tunnel in Vancouver, British Columbia, J. Air Waste Manage. Assoc., 48, 604-615, 1998.

Rubin, J. I., Kean, A. J., Harley, R. A., Millet, D. B., and Goldstein, A. H.: Temperature dependence of volatile organic compound evaporative emissions from motor vehicles, J. Geophys. Res., 111, D03305, doi:10.1029/2005JD006458, 2006.

Russo, R. S., Talbot, R. W., Dibb, J. E., Scheuer, E., Seid, G., Jordan, C. E., Fuelberg, H. E., Sachse, G. W., Avery, M. A., Vay, S. A., Blake, D. R., Blake, N. J., Atlas, E., Fried, A., Sand- holm, S. T., Tan, D., Singh, H. B., Snow, J., and Heikes, B. G.: Chemical composition of Asian continental outflow over the western Pacific: Results from Transport and Chemical Evolution over the Pacific (TRACE-P), J. Geophys. Res., 108, 8804, doi:10.1029/2002jd003184, 2003.

Russo, R. S., Zhou, Y., Haase, K. B., Wingenter, O. W., Frinak, E. K., Mao, H., Talbot, R. W., and Sive, B. C.: Temporal variability, sources, and sinks of C1-C5 alkyl nitrates in coastal New England, Atmos. Chem. Phys., 10, 1865-1883, doi:10.5194/acp10-1865-2010, 2010.

Sagebiel, J. C., Zielinska, B., Pierson, W. R., and Gertler, A. W.: Real-world emissions and calculated reactivities of organic species from motor vehicles, Atmos. Environ., 30, 2287-2296, 1996.

Scheff, P. A. and Wadden, R. A.: Receptor modeling of volatile organic compounds. 1. Emission inventory and validation, Environ. Sci. Technol., 27, 617-625, 1993.

Schnitzhofer, R., Beauchamp, J., Dunkl, J., Wisthaler, A., Weber, A., and Hansel, A.: Long-term measurements of $\mathrm{CO}, \mathrm{NO}, \mathrm{NO}_{2}$, benzene, toluene and $\mathrm{PM}_{10}$ at a motorway location in an Austrian valley, Atmos. Environ., 42, 1012-1024, 2008.

Sillman, S. and He, D. Y.: Some theoretical results concerning $\mathrm{O}_{3}-\mathrm{NO}_{\mathrm{x}}-\mathrm{VOC}$ chemistry and $\mathrm{NO}_{\mathrm{x}}$-VOC indicators, J. Geophys. Res., 107, 4659, doi:10.1029/2001jd001123, 2002.

Simmonds, P. G., Manning, A. J., Cunnold, D. M., McCulloch, A., O'Doherty, S., Derwent, R. G., Krummel, P. B., Fraser, P. J., Dunse, B., Porter, L. W., Wang, R. H. J., Greally, B. R., Miller, B. R., Salameh, P., Weiss, R. F., and Prinn, R. G.: Global trends, seasonal cycles, and European emissions of dichloromethane, trichloroethene, and tetrachloroethene from the AGAGE observations at Mace Head, Ireland, and Cape Grim, Tasmania, J. Geophys. Res., 111, D18304, doi:10.1029/2006jd007082, 2006.

Simpson, I. J., Meinardi, S., Blake, N. J., Rowland, F. S., and Blake, D. R.: Long-term decrease in the global atmospheric burden of tetrachloroethene $\left(\mathrm{C}_{2} \mathrm{Cl}_{4}\right)$, Geophys. Res. Lett., 31, L08108, doi:10.1029/2003g1019351, 2004.

Sistla, G. and Aleksic, N.: A comparison of PAMS and air toxics measurements, Atmos. Environ., 41, 5719-5731, doi:10.1016/j.atmosenv.2007.02.041, 2007.

Sive, B.: Atmospheric nonmethane hydrocarbons: Analytical methods and estimated hydroxyl radical concentrations, Ph.D. thesis, University of California-Irvine, California, 1998.

Sive, B. C., Zhou, Y., Troop, D., Wang, Y. L., Little, W. C., Wingenter, O. W., Russo, R. S., Varner, R. K., and Talbot, R.: Development of a cryogen-free concentration system for measurements of volatile organic compounds, Anal. Chem., 77, 69896998, doi:10.1021/ac0506231, 2005.

Sive, B. C., Varner, R. K., Mao, H., Blake, D. R., Wingenter, O. W., and Talbot, R.: A large terrestrial source of methyl iodide, Geophys. Res. Lett., 34, L17808, doi:10.1029/2007g1030528, 2007.

Shipham, M. C., Crill, P. M., Bartlett, K. B., Goldstein, A. H., Czepiel, P. M., Harriss, R. C., and Blaha, D.: Methane measurements in central New England: An assessment of regional transport from surrounding sources, J. Geophys. Res., 103, 2198522000, 1998.

Smyth, S., Sandholm, S., Shumaker, B., Mitch, W., Kanvinde, A., Bradshaw, J., Liu, S., McKeen, S., Gregory, G., Anderson, B., Talbot, R., Blake, D., Rowland, S., Browell, E., Fenn, M., Merrill, J., Bachmeier, S., Sachse, G., and Collins, J.: Characteri- 
zation of the chemical signatures of air masses observed during the PEM experiments over the western Pacific, J. Geophys. Res., 104, 16243-16254, 1999.

Swanson, A. L., Blake, N. J., Atlas, E., Flocke, F., Blake, D. R., and Rowland, F. S.: Seasonal variations of $\mathrm{C}_{2}-\mathrm{C}_{4}$ nonmethane hydrocarbons and $\mathrm{C}_{1}-\mathrm{C}_{4}$ alkyl nitrates at the Summit research station in Greenland, J. Geophys. Res., 108, 4065, doi:10.1029/2001jd001445, 2003.

Talbot, R., Mao, H. T., and Sive, B.: Diurnal characteristics of surface level O-3 and other important trace gases in New England, J. Geophys. Res., 110, D09307, doi:10.1029/2004jd005449, 2005.

Thompson, T. M., Butler, J. G., Daube, B. C., Dutton, G. S., Elkins, J. W., Hall, B. D., Hurst, D. F., King, D. B., Kline, E. S., Lafleur, B. G., Lind, J., Lovitz, S., Mondeel, D. J., Montzka, S. A., Moore, F. L., Nance, J. D., Neu, J. L., Romashkin, P. A., Scheffer, A., and Snible, W. J., Halocarbons and other atmospheric trace species, CMDL Summary Report \#27, 115-135, online available at: http://www.esrl.noaa.gov/gmd/publications/annrpt27/, 2004.

US Environmental Protenction Agency: National Air Quality and Emissions Trends Report, EPA 454/R-03-005, 2003.

US Environmental Protection Agency: National Air Emission Standards for Hazardous air pollutants: Halogenated solvent cleaning; Final Rule, 40 CFR Part 63, 2007.

US Environmental Protection Agency: Fuel Trends Report: Gasoline 1995-2005, EPA420-R-08-002, 2008.

Velasco, E., Lamb, B., Pressley, S., Allwine, E., Westberg, H., Jobson, B. T., Alexander, M., Prazeller, P., Molina, L., and Molina, M.: Flux measurements of volatile organic compounds from an urban landscape, Geophys. Res. Lett., 32, L20802, doi:10.1029/2005GL023356, 2005.

Velasco, E., Lamb, B., Westberg, H., Allwine, E., Sosa, G., ArriagaColina, J. L., Jobson, B. T., Alexander, M. L., Prazeller, P., Knighton, W. B., Rogers, T. M., Grutter, M., Herndon, S. C., Kolb, C. E., Zavala, M., de Foy, B., Volkamer, R., Molina, L. T., and Molina, M. J.: Distribution, magnitudes, reactivities, ratios and diurnal patterns of volatile organic compounds in the Valley of Mexico during the MCMA 2002 \& 2003 field campaigns, Atmos. Chem. Phys., 7, 329-353, doi:10.5194/acp-7-329-2007, 2007.

Wang, C. J. L., Blake, D. R., and Rowland, F. S.: Seasonal variations in the atmospheric distribution of a reactive chlorine compound, tetrachloroethene $\left(\mathrm{CCl}_{2}=\mathrm{CCl}_{2}\right)$, Geophys. Res. Lett., 22, 1097-1100, 1995.

Warneke, C., de Gouw, J. A., Stohl, A., Cooper, O. R., Goldan, P. D., Kuster, W. C., Holloway, J. S., Williams, E. J., Lerner, B. M., McKeen, S. A., Trainer, M., Fehsenfeld, F. C., Atlas, E. L., Donnelly, S. G., Stroud, V., Lueb, A., and Kato, S.: Biomass burning and anthropogenic sources of $\mathrm{CO}$ over New England in the summer 2004, J. Geophys. Res., 111, D23S15, doi:10.1029/2005JD006878, 2006.
Warneke, C., McKeen, S. A., de Gouw, J. A., Goldan, P. D., Kuster, W. C., Holloway, J. S., Williams, E. J., Lerner, B. M., Parrish, D. D., Trainer, M., Fehsenfeld, F. C., Kato, S., Atlas, E. L., Baker, A., and Blake, D. R.: Determination of urban volatile organic compound emission ratios and comparison with an emissions database, J. Geophys. Res., 112, D10S47, doi:10.1029/2006jd007930, 2007.

Watson, J. G., Chow, J. C., and Fujita, E. M.: Review of volatile organic compound source apportionment by chemical mass balance, Atmos. Environ., 35, 1567-1584, 2001.

White, A. B., Templeman, B. D., Angevine, W. M., Zamora, R. J., King, C. W., Russell, C. A., Banta, R. M., Brewer, W. A., and Olszyna, K. J.: Regional contrast in morning transitions observed during the 1999 Southern Oxidants Study Nashville/Middle Tennessee Intensive, J. Geophys. Res., 107, 4726, doi:10.1029/2001JD002036, 2003.

White, M. L., Russo, R. S., Zhou, Y., Mao, H., Varner, R. K., Ambrose, J., Veres, P., Wingenter, O. W., Haase, K., Stutz, J., Talbot, R., and Sive, B. C.: Volatile organic compounds in northern New England marine and continental environments during the ICARTT 2004 campaign, J. Geophys. Res., 113, D08S90, doi:10.1029/2007jd009161, 2008.

White, M. L., Russo, R. S., Zhou, Y., Ambrose, J. L., Haase, K., Frinak, E. K., Varner, R. K., Wingenter, O. W., Mao, H., Talbot, R., and Sive, B. C.: Are biogenic emissions a significant source of summertime atmospheric toluene in the rural Northeastern United States?, Atmos. Chem. Phys., 9, 81-92, doi:10.5194/acp9-81-2009, 2009.

Young, V. L., Kieser, B. N., Chen, S. P., and Niki, H.: Seasonal trends and local influences on nonmethane hydrocarbon concentrations in the Canadian boreal forest, J. Geophys. Res., 102(D5), 5913-5918, 1997.

Zhou, Y., Varner, R. K., Russo, R. S., Wingenter, O. W., Haase, K. B., Talbot, R., and Sive, B. C.: Coastal water source of short-lived halocarbons in New England, J. Geophys. Res., 110, D21302, doi:10.1029/2004jd005603, 2005.

Zhou, Y.: Atmospheric volatile organic compound measurements: Distributions and effects on air quality in coastal marine, rural, and remote continental environments, Ph.D. thesis, University of New Hampshire, Durham, NH, 2006.

Zhou, Y., Mao, H. T., Russo, R. S., Blake, D. R., Wingenter, O. W., Haase, K. B., Ambrose, J., Varner, R. K., Talbot, R., and Sive, B. C.: Bromoform and dibromomethane measurements in the seacoast region of New Hampshire, 2002-2004, J. Geophys. Res., 113, D08305, doi:10.1029/2007jd009103, 2008. 